\title{
Expression of extracellular matrix proteins and integrins in rat adrenal gland: importance for ACTH-associated functions
}

\author{
Mélissa Otis ${ }^{1, *}$, Shirley Campbell ${ }^{2, *}$, Marcel D Payet ${ }^{\mathbf{2}}$ and Nicole Gallo-Payet ${ }^{\mathbf{1}}$ \\ ${ }^{1}$ Service of Endocrinology, ${ }^{2}$ Department of Physiology and Biophysics, Faculty of Medicine and Health sciences, University of Sherbrooke, Sherbrooke, 3001, \\ 12th Avenue North, Quebec, Canada J1H 5N4 \\ (Requests for offprints should be addressed to N Gallo-Payet; Email: nicole.gallo-payet@usherbrooke.ca) \\ *(M Otis and S Campbell contributed equally to this work)
}

\begin{abstract}
The expression of main extracellular matrix (ECM) and their integrins were studied in the adult rat adrenal gland. Collagen I, IV (CI, CIV), laminin (LN) and fibronectin (FN) expression was observed surrounding each glomerulosa cell and as long fibrils between the cords of fasciculata cells. In the medulla, FN was present around chromaffin cells or bordering blood vessels. Integrin $\alpha 2, \alpha 3$ and $\alpha 5$ were present mainly in the cortex, while $\alpha 1$ was present in the medulla. In culture, all ECM favoured proliferation of both glomerulosa and fasciculata cells, while protein synthesis was lower on FN and LN in glomerulosa cells. CIV promoted ACTH-induced proliferation whereas FN favoured ACTH-induced protein synthesis in glomerulosa cells. Except for LN, ECM increased expression of 3 $\beta$-hydroxysteroid dehydrogenase and enhanced basal aldosterone, although corticosterone secretion
\end{abstract}

was only enhanced by CI and CIV. In fasciculata cells, the potency of ACTH-induced cAMP production was lower on ECM, compared with plastic. Moreover, ACTH, but not ECM, activated mitogenic-activated protein kinase p38 and stress-activated protein kinases. Glomerulosa and fasciculata cells grown on CI and CIV had a polygonal morphology, while cells grown on LN appeared as clusters of small rounded cells. On FN, the glomerulosa cells exhibited polygonal morphology while fasciculata cells appeared as clusters of small rounded cells. Together, these results indicate that ECM modulates basal and ACTH-induced cell functions, with FN, CI and CIV specifically favouring steroid secretion, as opposed to LN which inhibits secretion while promoting proliferation.

Journal of Endocrinology (2007) 193, 331-347

\section{Introduction}

The adult rat adrenal cortex is composed of three concentric layers, the zona glomerulosa, the zona fasciculata and the zona reticularis, all of which present different morphological and functional properties. The zona glomerulosa secretes aldosterone while the zona fasciculata secretes glucocorticoids. Adrenocorticotrophic hormone (ACTH) is the most potent stimulus of both corticosterone and aldosterone secretion and acts not only on the immediate, transcription-independent stimulation of adrenal steroid synthesis and release, but also increases the expression of a number of genes including those involved in steroidogenesis (Rainey 1999, Sewer \& Waterman 2003). Most actions of ACTH are mediated through cAMP and subsequent activation of protein kinase A (Penhoat et al. 2001, Gallo-Payet \& Payet 2003). In addition, in the Y1 adrenocortical cell line, ACTH may also activate the mitogenic-activated protein kinase pathway, p42/p44 (p42/ p44 ${ }^{\text {mapk}}$; Watanabe et al. 1997, Lotfi \& Armelin 2001) and the stress-activated protein kinases (SAPK)/c-Jun N-terminal kinases (JNK) (Watanabe et al. 1997, Forti et al. 2006). This family of mitogen-activated protein kinases (MAPKs) can induce a number of cellular functions, including proliferation, migration, hypertrophy and differentiation (Houslay \& Kolch 2000). In vivo, ACTH does not exhibit the same steroidogenic potency on zona glomerulosa and zona fasciculata. For instance, it is well established that hypophysectomy decreases the volume of zona fasciculata, without affecting the zona glomerulosa (Cater \& Stack-Dunne 1953), while ACTH treatment increases the overall volume of the cortex (Mazzocchi et al. 1986) and vascularization (Thomas et al. 2003, 2004). From these observations, we raised the hypothesis that the nature of extracellular matrix (ECM) and integrins could influence cell responses to $\mathrm{ACTH}$, as also observed in the human foetal adrenal gland (Chamoux et al. 2002).

Several studies have shown that the extracellular microenvironment can orchestrate a number of cell functions such as proliferation, differentiation, migration, survival and steroidogenesis (Le Bellego et al. 2002, Wang \& Milner 2006, for a review see Giancotti 2000, Schwartz 2001). For example, in the bovine adrenal gland, laminin (LN) is mainly associated with migration (Pellerin et al. 1997, Feige et al. 1998). On the other hand, in rat adult glomerulosa cells, we 
have shown that adhesion of glomerulosa cells to fibronectin (FN) is able to promote an increase in intracellular calcium, activate $\mathrm{p} 42 / \mathrm{p} 44^{\mathrm{mapk}}$ and stimulate proliferation and aldosterone secretion (Campbell et al. 2003). The ECM proteins interact with cells through binding of integrin receptors localized on plasma cell membranes (Tamkun et al. 1986). The integrins are transmembrane proteins comprised of two subunits, alpha $(\alpha)$ and beta $(\beta)$ and constitute the predominant family of proteins mediating cell-matrix interactions, responsible for transduction and activation of several intracellular cascades (Hynes 1992, Aplin et al. 1998, Giancotti \& Tarone 2003). Previous results (RT-PCR and western blot analyses) indicate that $\alpha_{\mathrm{V}}, \alpha_{5}, \beta_{1}$ and $\beta_{3}$ subunits are expressed in the rat adrenal glomerulosa cells (Campbell et al. 2003). Integrin $\alpha_{5} \beta_{1}$ is specific for $F N$, although integrins $\alpha_{3} \beta_{1}, \alpha_{4} \beta_{1}, \alpha_{\mathrm{x}} \beta_{2}, \alpha_{\mathrm{v}} \beta_{3}$ and $\alpha_{\mathrm{v}} \beta_{6}$ can also bind FN. It is also well-known that integrins $\alpha_{1} \beta_{1}, \alpha_{2} \beta_{1}, \alpha_{3} \beta_{1}$ and $\alpha_{v} \beta_{1}$ can bind collagen by different recognition sites, while LN-binding integrins include $\alpha_{1} \beta_{1}, \alpha_{2} \beta_{1}, \alpha_{3} \beta_{1}, \alpha_{6} \beta_{1}, \alpha_{7} \beta_{1}$ and $\alpha_{6} \beta_{4}$ (for review, see Gonzalez et al. 1999, Mizejewski 1999, van der Flier \& Sonnenberg 2001).

To our knowledge, there is no information on the in situ expression and localization of ECM and integrins in the adult rat adrenal gland and of the effects of these matrix components on basal adrenal functions and hormonal action. Hence, the aim of the present study was to verify the relative expression of the main ECM components (collagen, FN and $\mathrm{LN}$ ) and their integrin receptors in the adult rat adrenal gland (cortex and medulla) and to investigate whether the nature of the ECM is able to modulate the effects of ACTH on secretion, proliferation and protein synthesis in both glomerulosa and fasciculata cells.

\section{Material and Methods}

\section{Chemicals}

The chemicals used in the present study were obtained from the following sources: minimum essential medium (MEM; Eagle's medium) and OPTI-MEM medium from Life Technologies; ACTH (1-24) peptide (Cortrosyn) was purchased from Organon (Toronto, Canada) and ACTH (1-39) peptide (Synacthen) was from Novartis (Dorval, QC, Canada). Matrix-coated dishes and coated 24- and 96-well plates (collagen I, CIV(CI, IV); FN and LN) were obtained from BD-VWR Canlab (Ville Mont-Royal, QC, Canada). The rabbit anti-LN antibody from Sigma; rabbit anti-FN, rabbit anti-CI and rabbit anti-dopamine $\beta$-hydroxylase (DBH) antibodies from Chemicon International (Temecula, CA, USA), and anti-CIV from Cedarlane (Hornby, Ont., Canada). The antibodies against $\beta 1, \alpha 1, \alpha 2, \alpha 3$ and $\alpha 5$ integrins subunits were all from Chemicon International. The anti-phosphorylated p38 MAPK, anti-phosphorylated SAPK, anti-p38 MAPK and anti-SAPK antibodies were obtained from New England Biolabs, Inc. (Mississauga, Ont., Canada).

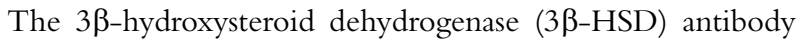
was from Dr Van Luu-The (CHUL Research Center, Ste-Foy, QC, Canada). Unmasking antigen solution, normal serum and Vectashield mounting mediums were all from Vector Laboratories (Burlingame, CA, USA). Anti-mouse Alexa-Fluor488 nm and $594 \mathrm{~nm}$, anti-rabbit AlexaFluor488 nm and $594 \mathrm{~nm}$, Zenon Alexa Fluor 488 and Zenon Alexa Fluor 594 labelling kits, 4',6'-diamino-2phenylindole (DAPI), 5-bromo-2-deoxyuridine (BrdU) anti-BrdU Alexa Fluor-594 were from Molecular Probes (Eugene, OR, USA). Collagenase, $\left[{ }^{3} \mathrm{H}\right]$ aldosterone $(76 \mu \mathrm{Ci} / \mathrm{mmol})$ and $\left[{ }^{3} \mathrm{H}\right]$ corticosterone $(70 \mu \mathrm{Ci} / \mathrm{mmol})$ were purchased from New England Nuclear (Boston, MA, USA); aldosterone and corticosterone antiserum from ICN Biochemicals (Costa Mesa, CA, USA); isobutylmethylxanthine (IBMX), cAMP and ATP were purchased from Sigma-Aldrich Corp. (Oakville, Canada). All other chemicals were of A-grade purity.

\section{Immunofluorescence}

Use of antibodies was optimized using either paraffin or frozen sections. Tissue sections from paraffin-embedded adrenal glands were used to determine the presence of integrin subunits within the whole adrenal gland, while frozen sections were used to determine the presence of ECM components. Adult adrenal glands from female Long Evans rats $(250 \mathrm{~g})$ were removed and snap-frozen in optimal cutting temperature. Animal protocols were approved by our institution's (Faculté de médecine et des sciences de la santé, Université de Sherbrooke) Animal Care and Ethics Committee and conducted according to ethical guidelines from the Canadian Council on Animal Care. For ECM localization experiments, 5-6 $\mu \mathrm{m}$ frozen sections were fixed with $3 \cdot 7 \%$ formaldehyde for $15 \mathrm{~min}$ at $4{ }^{\circ} \mathrm{C}$, washed in PBS $\left(136.89 \mathrm{mM} \mathrm{NaCl} ; 2.68 \mathrm{mM} \mathrm{KCl} ; 18.88 \mathrm{mM} \mathrm{Na}_{2} \mathrm{HPO}_{4}\right.$ and $1.76 \mathrm{mM} \mathrm{KH}_{2} \mathrm{PO}_{4}, \mathrm{pH} \mathrm{7.4)}$ and incubated with glycine $0 \cdot 1 \mathrm{M}$ for $30 \mathrm{~min}$ at room temperature. Sections were then treated with $0.2 \%$ Triton $\mathrm{X}-1000$, washed and incubated with $1 \cdot 5 \%$ normal goat serum for $45 \mathrm{~min}$. Antibody dilutions were as follows: anti-CI (1:50); anti-CIV (1:80); anti-FN (1:50) and anti-LN (1:50). The antibody used for LN detection recognized LN isoform-1. Overnight incubation with the primary antibodies was followed by incubation with a secondary goat antibody conjugated to Alexa Fluor 488. Sections were washed with PBS, the nuclei stained with DAPI and sections mounted with Vectashield mounting medium for subsequent observation. Non-specific labelling was assessed by boiling the primary antibodies for $15 \mathrm{~min}$.

For double staining immunofluorescence of ECM components, antibodies derived from the same species were directly labelled with Zenon Alexa Fluor 488 and Zenon Alexa Fluor 594. For ECM components and DBH labelling (a marker of chromaffin cell functionality), the ECM component antibodies were conjugated with Zenon Alexa Fluor 488 Rabbit IgG Labelling Kit, while the anti-DBH 
antibody was detected with a goat anti-rabbit antibody conjugated to Alexa Fluor 594.

For integrin immunostaining, $5 \mu \mathrm{m}$ thick sections of rat adrenal glands were fixed in formalin and embedded in paraffin. After removal of paraffin and rehydration of tissue sections according to classical histological procedures, sections were immersed in $0 \cdot 1 \% \mathrm{SDS} / \mathrm{H}_{2} \mathrm{O}$ and washed with PBS. Antibody dilutions were as follows: anti- $\alpha 1,-\alpha 2,-\alpha 3$ and $-\alpha 5$ (1:500). Overnight incubation with primary antibodies was followed by incubation with a secondary goat antibody conjugated with Alexa Fluor 488. Sections were washed with PBS, nuclei stained with DAPI and sections mounted with Vectashield mounting medium for subsequent observation. Non-specific labelling was assessed by boiling the primary antibodies for $15 \mathrm{~min}$. Images were acquired with a Hamamatsu ORCA-ER digital camera attached to Nikon Eclipse TE-2000 inverted microscope (Nikon Canada, Mississanga, Canada) equipped for epi-illumination.

\section{Image analysis of colocalized ECM components}

Binary images were generated for respective acquisitions of fluorescent ECM components using Metamorph (version 4.6r10) software (Universal Imaging Corporation, Downingtown, PA, USA). The binary images for each pair of ECM components under study were analysed using a Boolean operation to determine the colocalization of ECM components. Data are representative illustrations of three to six slides prepared from three different animals.

\section{Preparation of cell cultures}

Glomerulosa and fasciculata cells were obtained from adrenal glands of female Long Evans rats weighing 200-250 g, and isolated according to the method previously described in detail (Gallo-Payet \& Payet 1989). All protocols were approved by the Animal Care and Ethics Committee of our institution. Isolation and cell dissociation of the zona glomerulosa were performed in MEM (supplemented with $100 \mathrm{U} / \mathrm{ml}$ penicillin and $100 \mu \mathrm{g} / \mathrm{ml}$ streptomycin). After a $20 \mathrm{~min}$ incubation at $37^{\circ} \mathrm{C}$ with collagenase $(2 \mathrm{mg} / \mathrm{ml})$ and DNase $(25 \mu \mathrm{g} / \mathrm{ml})$, cells were disrupted by gentle aspiration with a sterile $10 \mathrm{ml}$ pipette, filtered and centrifuged for $10 \mathrm{~min}$ at $100 \mathrm{~g}$. The cell pellet was then resuspended in OPTI-MEM medium supplemented with $2 \%$ FBS, $100 \mathrm{U} /$ $\mathrm{ml}$ penicillin and $100 \mu \mathrm{g} / \mathrm{ml}$ streptomycin.

According to experimental conditions, cells were plated at various densities on plastic or on FN, LN, CI or IV-coated Petri dishes (at $5 \times 10^{4}$ cells for morphology and at $2 \times$ $10^{5}$ cells/well for steroid secretion) or 96-multiwell plates (at $30 \times 10^{3}$ cells/well for proliferation assays). Matrix-coated dishes and plates were derived from different sources: CI from rat tail tendon, CIV from engelbreth-holm-swarm (EHS) mouse tumour, FN from human plasma and LN-111 from EHS mouse tumour, with purity $>90 \%$. According to BD Biosciences, the LN is made primarily of $\mathrm{LN}-1$ (LN-111) derived from the mouse ESH tumour and LN-111 is not cross linked and it is just attached to a surface. Cells were cultured at $37^{\circ} \mathrm{C}$ in a humidified atmosphere composed of $95 \%$ air $-5 \%$ $\mathrm{CO}_{2}$. The culture medium was changed daily and the cells were used after 3 days of culture. Cells were examined daily and phase-contrast images were acquired using a Leica microscope (Deerfield, IL, USA) equipped with a $32 \times$ objective and a Canon digital camera.

\section{Proliferation assays}

Cell proliferation was measured using fluorescence BrdU incorporation, as described previously (Otis et al. 2005). Cells were plated on plastic (PL), CI-, CIV-, LN- or FN-coated 96-well plates, at a concentration of $3 \times 10^{4}$ cells $/$ well. Cells were treated daily for 3 days without or with ACTH $(10 \mathrm{nM})$ alone or in the presence of various inhibitors. After $24 \mathrm{~h}$ of culture, $10 \mu \mathrm{M} \mathrm{BrdU}$ were added to the culture medium $4 \mathrm{~h}$ prior to stimulation with ACTH $(10 \mathrm{nM})$. On the third day, cells were fixed with $3 \cdot 7 \%$ (vol/vol) formaldehyde in Hanks' buffered saline (HBS) for $10 \mathrm{~min}$ at room temperature, followed by a $10-$ min permeabilization treatment with $0 \cdot 2 \%$ Triton X-100 in HBS. Cells were then incubated with antiBrdU Alexa Fluor-594 (1:500). Fluorescence intensity was measured using a Microplate Fluorescence Reader FL600 (Bio-Tek; excitation: 560/40 nm; emission: 645/40 nm). Results are expressed as the percent of variation from basal conditions using six culture wells for each experimental condition. Cell number was also assessed using a standard haemacytometer.

\section{Protein synthesis measurements}

The relative amount of protein synthesis was determined by assessing tritiated phenylalanine incorporation. Cells were plated on plastic or matrix-coated 24-well plates at a concentration of $70 \times 10^{3}$ cells/well. After $24 \mathrm{~h}$ of culture, $1 \mu \mathrm{Ci} / \mathrm{ml}\left[{ }^{3} \mathrm{H}\right]$ phenylalanine was added to the media $2 \mathrm{~h}$ prior to stimulation with ACTH $(10 \mathrm{nM})$. After 3 days, the medium was aspirated and the cells washed thrice with cold HBS solution, followed by addition of trichloroacetic acid (TCA) solution (20\%) for $20 \mathrm{~min}$ on ice. After centrifugation $\left(3000 \mathrm{~g}, 15 \mathrm{~min}, 4^{\circ} \mathrm{C}\right)$, the TCA-insoluble fraction was washed twice with TCA solution and solubilized in $0 \cdot 1 \mathrm{M}$ $\mathrm{NaOH}$ solution for $1 \mathrm{~h}$ on ice. Incorporation of radioactivity was measured by liquid scintillation counting (Beckmann counter). Data were normalized as maximum of phenylalanine incorporation in control conditions for the same number of cells $\left(1 \times 10^{5}\right.$ cells), as described by Otis et al. (2005).

\section{Steroid measurements}

Prior to each experiment, the medium from cultured cells was aspirated and cells were washed twice with cold (HBS; $130 \mathrm{mM} \mathrm{NaCl}, 3.5 \mathrm{mM} \mathrm{KCl}, 1.8 \mathrm{mM} \mathrm{CaCl}_{2}, 0.5 \mathrm{mM}$ 
$\mathrm{MgCl}_{2}, 2 \cdot 5 \mathrm{mM} \mathrm{NaHCO}$, and $5 \mathrm{mM} \mathrm{HEPES)} \mathrm{supple-}$ mented with $1 \mathrm{~g} / 1$ glucose and $0 \cdot 5 \%$ BSA. Cells were incubated in a $1 \mathrm{ml}$ solution consisting of $0.9 \mathrm{ml} \mathrm{HBS}$ glucose supplemented with $0 \cdot 5 \%$ BSA-0.1 $\mathrm{mg} / \mathrm{ml}$ bacitracin and $0.1 \mathrm{ml} \mathrm{ACTH}(10 \mathrm{nM})$. Following a $2 \mathrm{~h}$ incubation at $37^{\circ} \mathrm{C}$ in a $95 \%$ air-5\% $\mathrm{CO}_{2}$ environment, the incubation medium was removed by aspiration and stored at $-20{ }^{\circ} \mathrm{C}$ until assayed for steroid content. The latter was determined by RIA, using specific antisera and tritiated steroid as tracer.

\section{Western blotting}

Cells were cultured onto plastic, CI-, CIV-, LN- or FN-coated dishes at a concentration of $5 \times 10^{5}$ cells/Petri dish, with cell density reaching $\sim 1 \times 10^{6}$ cells/Petri dish after 3 days of culture. For activation of p38MAPK and SAPK/JNK, cells were cultured for 3 days and stimulated without or with ACTH $(10 \mathrm{nM})$ for $30 \mathrm{~min}$. For $3 \beta-H S D$ expression, cells were cultured for 3 days. The cells were lysed with $30 \mu \mathrm{l} 50 \mathrm{mM}$ HEPES (pH 7·8), $100 \mathrm{nM}$ staurosporine, $1 \mathrm{mM}$ sodium orthovanadate and $1 \%$ Triton $\mathrm{X}-100$. The insoluble material was pelleted at $15000 \mathrm{~g}$ for $15 \mathrm{~min}$ at $4{ }^{\circ} \mathrm{C}$. Samples from an equivalent amount of protein $(30 \mu \mathrm{g}$ protein) were separated on 10\% SDSpolyacrylamide gels and proteins transferred electrophoretically onto polyvinylidene difluoride membranes. Membranes were blocked with $1 \%$ gelatin and $0 \cdot 05 \%$ Tween 20 in Tris-buffered saline $(\mathrm{pH} \mathrm{7 \cdot 5)}$. After three washes with TBS-Tween $20(0 \cdot 05 \%)$, membranes were incubated with anti-phospho-p38MAPK (1:1000), anti-phospho-SAPK (1:1000), anti-3 $\beta-H S D$ (dilution 1:500). Detection was performed by reaction with horseradish peroxidase-conjugated secondary antibody and visualized by enhanced chemiluminescence according to the manufacturer's instructions. The same blots were reprobed for total p38MAPK with anti-p38MAPK $(1: 1000)$, for total SAPK with antiSAPK (1:1000; data not shown) or with anti-tubulin (dilution 1:500). The immunoreactive bands were scanned by laser densitometry and expressed in arbitrary units.

\section{cAMP accumulation}

Cells were cultured on plastic, CI-, CIV-, LN- or FN-coated dishes with cell density reaching $\sim 3 \times 10^{5}$ cells/Petri dish after 3 days of culture. Intracellular cAMP production was determined by measuring the conversion of $\left[{ }^{3} \mathrm{H}\right]$ ATP into $\left.{ }^{3} \mathrm{H}\right]$ cAMP as previously described (Gallo-Payet \& Payet 1989). Briefly, cells were incubated at $37^{\circ} \mathrm{C}$ in OPTI-MEM culture medium containing $2 \mu \mathrm{Ci} / \mathrm{ml}\left[{ }^{3} \mathrm{H}\right] \mathrm{ATP}$. After $1 \mathrm{~h}$, the cells were washed with cold HBS supplemented with $1 \mathrm{~g} / 1$ glucose and $0 \cdot 1 \%$ BSA, followed by the addition of $1 \mathrm{mM}$ 3-isobutyl-1-methylxanthine (IBMX; $15 \mathrm{~min}$ at $37^{\circ} \mathrm{C}$ ) and by the addition of increasing concentrations of ACTH. After an additional $15 \mathrm{~min}$ incubation period at $37^{\circ} \mathrm{C}$, cells were collected, solubilized and chromatographed on Dowex and alumina columns as previously described (Gallo-Payet \&
Payet 1989). Cyclic AMP accumulation was expressed as: percentage conversion $=\left(\left[{ }^{3} \mathrm{H}\right] \mathrm{cAMP} /\left(\left[{ }^{3} \mathrm{H}\right] \mathrm{cAMP}+\right.\right.$ $\left.\left.\left[{ }^{3} \mathrm{H}\right] \mathrm{ATP}\right)\right) \times 100 / 15 \mathrm{~min}$ by $2 \times 10^{5}$ cells.

\section{Data analysis}

The data are presented as means \pm s.E.M. of the number of experiments indicated in parentheses. Homogeneity of variance was assessed by one-way ANOVA followed by Bartlett's test; $P$ values were obtained from Dunnett's tables.

\section{Results}

\section{Detection of ECM components in whole rat adrenal gland}

Using indirect immunofluorescence, CI, CIV, LN and FN staining was examined in both the adrenal cortex and medulla. CI staining was mainly expressed in the capsule and surrounding each glomerulosa cell and as thin fibrils in the zona fasciculata (Fig. $1 \mathrm{Aa}$ and $\mathrm{Ab}$, inset). CIV exhibited only moderate labelling in the capsule but, as $\mathrm{CI}$, was observed surrounding each cell (Fig. 1Ba and Bb, inset), while in the zona fasciculata, CIV presented as long thick fibrils between the radial cords of fasciculata cells (Fig. 1Bb). LN was observed primarily in the zona glomerulosa, with short fibrils penetrating both the zonae fasciculata and reticularis (Fig. $1 \mathrm{Ca}$ and $\mathrm{Cb}$ ). FN staining was moderate in the capsule, while strong labelling was observed surrounding each glomerulosa cell and as discontinuous fibrils throughout the cortex (Fig. 1Da and $\mathrm{Db}$ ). Except for CIV, labelling was generally weak in the zona reticularis. Non-specific FN, LN, CI and CIV staining is shown in Fig. 1Ac to Dc.

Expression of ECM components in the cortex was compared with their expression in the medulla (Fig. 2), where chromaffin cells were identified by immunoreactivity to an anti-DBH enzyme. CI was expressed around each individual chromaffin cell and around each cluster of cells (Fig. 2A and E, arrow). In contrast, CIV and LN were expressed solely around clusters of chromaffin cells (Fig. 2B and $\mathrm{C}$ and magnification, $\mathrm{F}$ and $\mathrm{G}$, arrows), while $\mathrm{FN}$ was restricted to the border of blood vessels (Fig. 2D and $\mathrm{H}$ ).

\section{Detection of integrin subunits in the whole rat adrenal gland}

The $\beta 1$ integrin subunit is ubiquitous. Indeed, the presence of this subunit in the adrenal gland was verified using paraffinembedded sections. Integrin subunit $\beta 1$ was observed throughout the cortex (Fig. 3A) with labelling found surrounding both glomerulosa and fasciculata cells (Fig. 3B, arrows and inset). Figure 3C shows non-specific labelling for integrin subunit $\beta 1$.

Since the specificity of integrin interaction is achieved through the association of the $\beta$ subunit with various $\alpha$ subunits, integrin $\alpha$ subunit expression was thus investigated. 


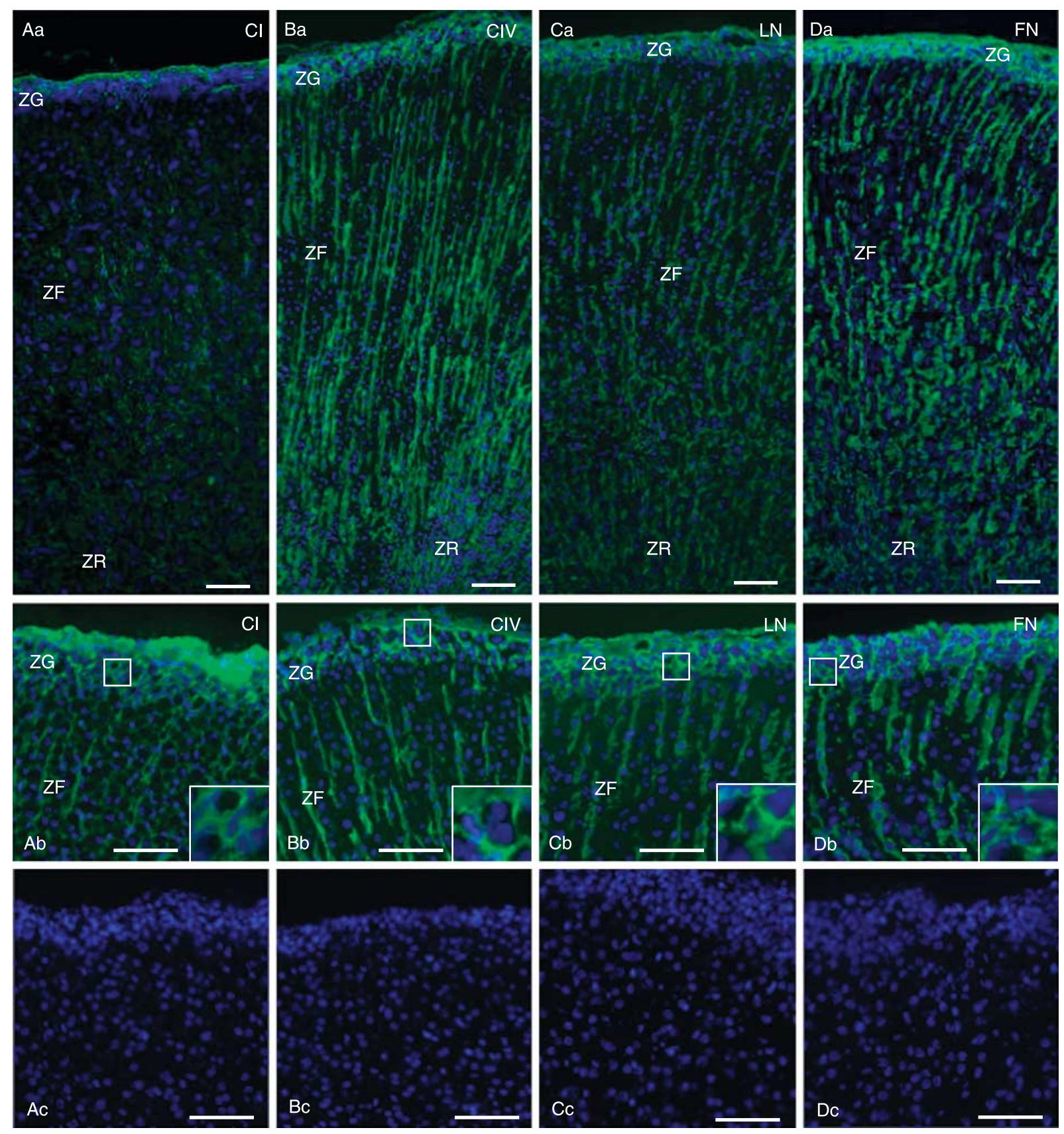

Figure 1 Immunodetection of collagen I (CI), collagen IV (CIV), laminin (LN) and fibronectin (FN) in adult rat adrenal gland cortex. Frozen sections $(5-6 \mu \mathrm{m})$ of adult rat adrenal gland were processed by indirect immunofluorescence as described in Materials and Methods. Nuclei were stained with DAPI. Aa and Ab: Cl; Ba and Bb: CIV; Ca and Cb: LN; Da and Db: FN. Non-specific staining for CI (Ac), CIV (Bc), LN (Cc) and FN (Dc). Images were acquired at magnification $10 \times$ (Aa, Ba, Ca and Da) and $30 \times$ (Abc, Bbc, Cbc and Dbc). Scale bars, $50 \mu \mathrm{m}$. Insets magnification: $\times 300$. Images are representative illustrations of more than five glands.

Integrin subunit $\alpha 1$ exhibited a low level of expression in the cortex (Fig. 4Aa and Ac), but was strongly expressed in the medulla (Fig. 4Aa and Ab). Variances in localization within the cortex and medulla were exemplified in medullary rays (Fig. 4Aa, arrow), or islets of specific chromaffin cells in the cortex (Fig. 4Aa and Ac, arrow head); $\alpha 2, \alpha 3$ and $\alpha 5$ were strongly expressed in the cortex (Fig. 4Ba and Bc, Ca and Cc and Da and Dc respectively), but absent in the medulla, except for some scattering in a small population of cells (Fig. 4Bb, $\mathrm{Cb}$ and $\mathrm{Db}$, arrow heads). Indeed, $\alpha 3$ staining was higher in the cortex but barely detectable in the medulla, medullary rays and chromaffin cells in the cortex. 

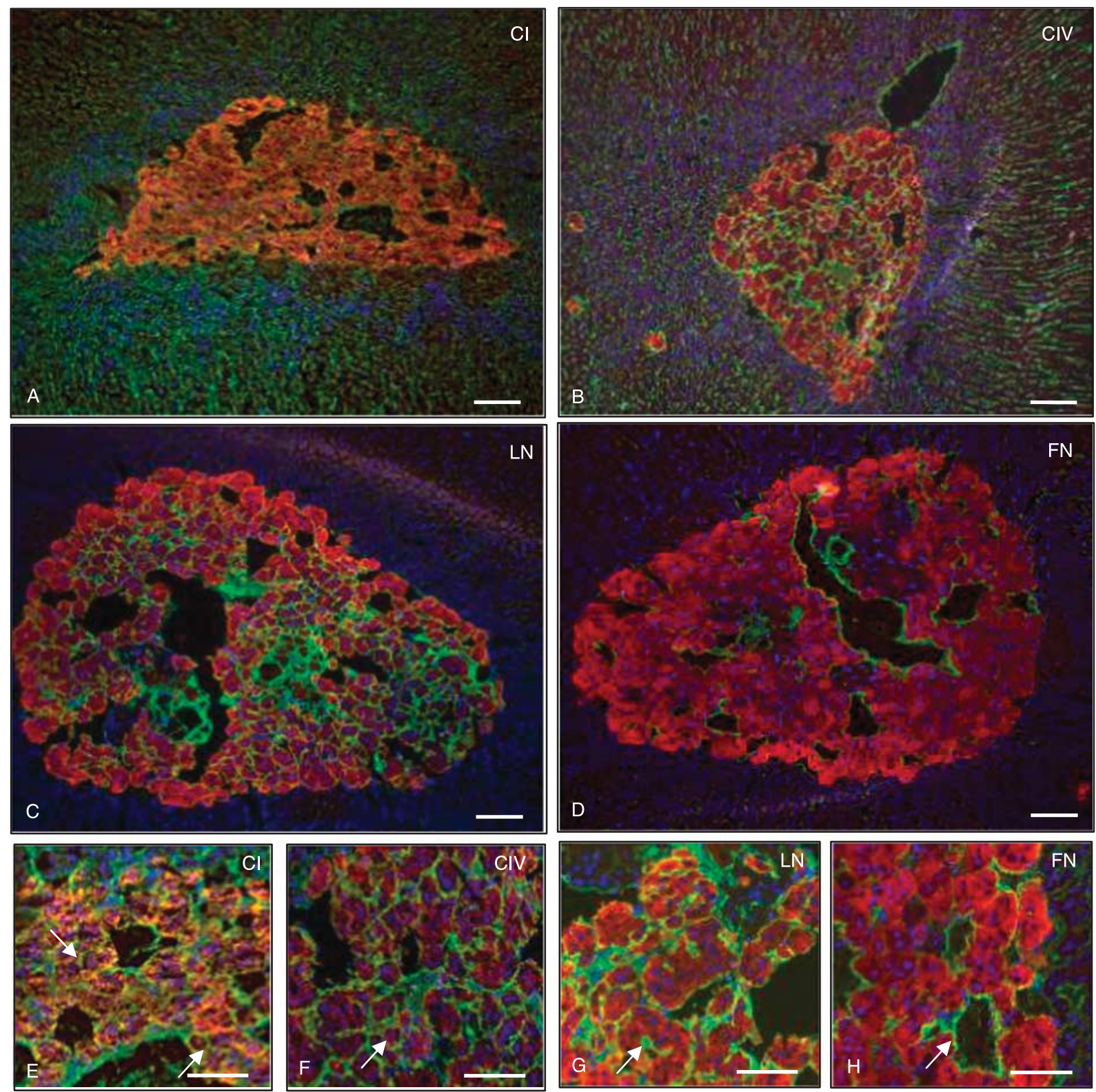

Figure 2 Double immunofluorescence of collagen I (CI), collagen IV (CIV), laminin (LN), fibronectin (FN) and dopamine $\beta$ hydroxylase enzyme $(\mathrm{DBH})$ in adult rat adrenal gland medulla. Frozen sections $(5-6 \mu \mathrm{m})$ of adult rat adrenal gland were processed for double immunofluorescence with Zenon technology as described in Materials and Methods. ECM components were labelled with Zenon Alexa Fluor 488 (green) and DBH with Zenon Alexa Fluor 594 (red). A and E: Cl and DBH; B and F: CIV and DBH; C and G: LN and DBH; D and H: $\mathrm{FN}$ and $\mathrm{DBH}$. Arrows point expression of $\mathrm{Cl}$ around each individual chromaffin cell and around each cluster of cells (2E), expression of $\mathrm{CIV}(2 \mathrm{~F})$ and $\mathrm{LN}(2 \mathrm{G})$ around clusters of chromaffin cells, expression of $\mathrm{FN}(2 \mathrm{H})$ at the border of blood vessels. Images were acquired at magnification $10 \times(A-D)$ and $30 \times(E-H)$. Scale bars, $50 \mu \mathrm{m}$. Images are representative illustrations of more than five glands.

Functional properties of ACTH in cells cultured on various extracellular matrices

Proliferation and protein synthesis Glomerulosa cells easily proliferate in culture (doubling in 2 days) compared with fasciculata cells, which grow much more slowly (Gallo-Payet \& Payet 1989, Gallo-Payet et al. 1993). Basal proliferation of glomerulosa and fasciculata cells was stimulated on all ECMs tested when compared with plastic conditions, with the highest rate observed on CIV (Fig. 5A and B). Basal protein synthesis of glomerulosa cells was lower on FN and LN than on CI, CIV or plastic (Fig. 5C), whereas basal protein content of fasciculata cells was not affected by the various matrices (Fig. 5D). In glomerulosa cells, addition of ACTH (10 nM) for 3 days increased proliferation 

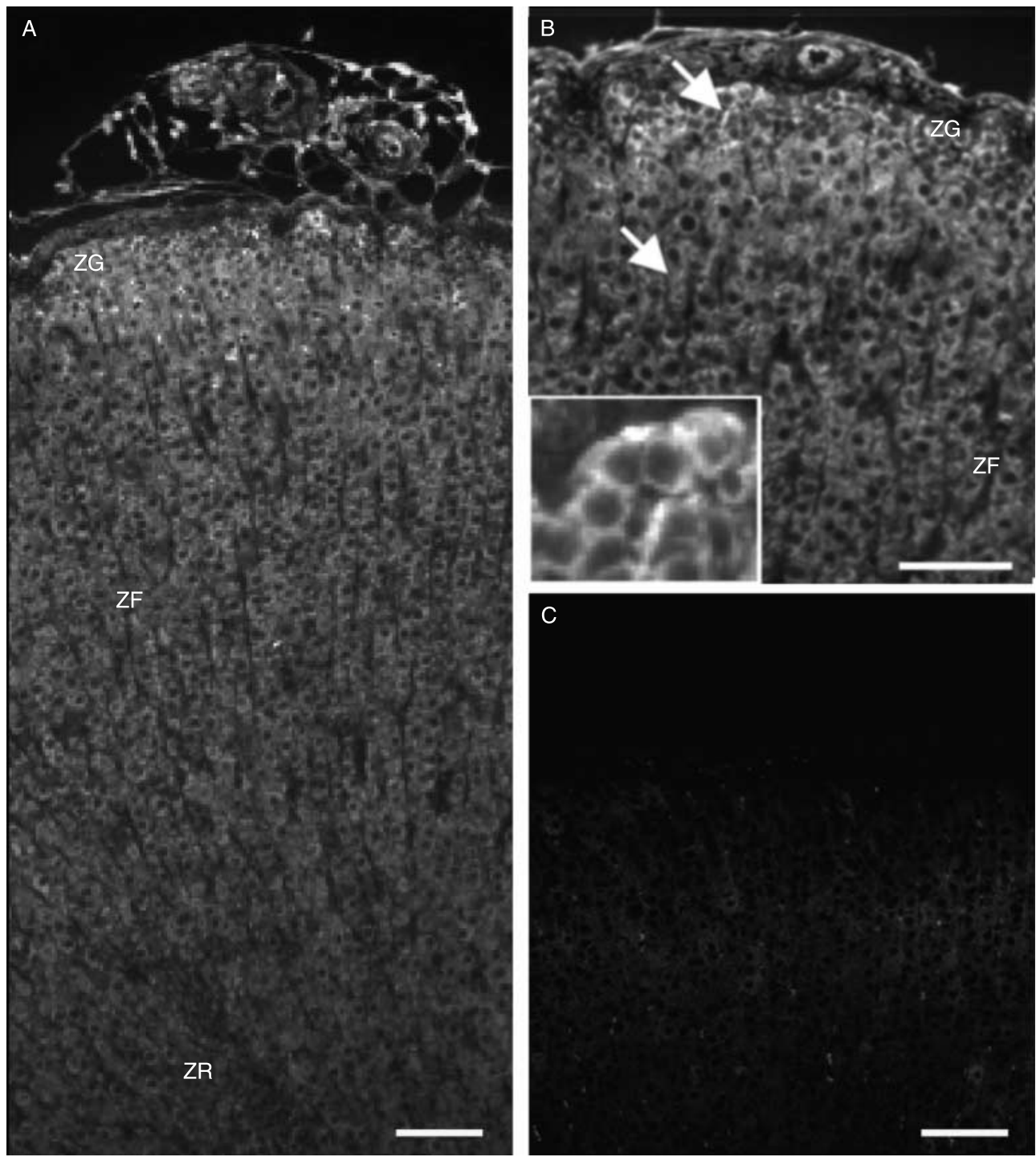

Figure 3 Immunodetection of integrin $\beta 1$ subunit in adult rat adrenal gland. Paraffin-embedded sections $(5 \mu \mathrm{m})$ of adult rat adrenal gland were processed for immunofluorescence labelling as described in Materials and Methods. A: $\beta 1$ subunit expression in the adrenal cortex; $B$ : $\beta 1$ subunit in the adrenal cortex outer zone; $C$ : non-specific labelling for $\beta 1$ subunit in the adrenal cortex. Arrow in B points to expression of integrin subunit $\beta 1$ surrounding both glomerulosa and fasciculata cells. Scale bars, $50 \mu \mathrm{m}$. Insets magnification: $\times 300$. Images are representative illustrations of more than five glands.

by $1 \cdot 6 \pm 0 \cdot 1$-fold on CIV and by $2 \cdot 0 \pm 0 \cdot 1$-fold over control on FN, but not on LN and CI (Fig. 5A) and only on CIV in fasciculata cells $(1 \cdot 7 \pm 0 \cdot 1$-fold; Fig. $5 \mathrm{~B})$. ACTH treatment increased protein synthesis in glomerulosa cells grown on plastic $(1 \cdot 9 \pm 0 \cdot 1$-fold $)$ and FN $(2 \cdot 9 \pm 0 \cdot 1$-fold; Fig. 5C). All matrices, except $\mathrm{LN}$, increased the effect of ACTH on protein synthesis in fasciculata cells (with the following order of potency; $2 \cdot 3 \pm 0 \cdot 1$-fold on FN, $1 \cdot 9 \pm 0 \cdot 1$-fold on CIV, $1 \cdot 8 \pm$ $0 \cdot 1$-fold on CI, compared with $1 \cdot 8 \pm 0 \cdot 1$ fold on plastic conditions; Fig. 5D).
Secretion of aldosterone and corticosterone Glomerulosa cells cultured on CI and CIV were able to produce more aldosterone than on plastic alone, with respective fold increases of $1 \cdot 4 \pm 0 \cdot 1$ and $1 \cdot 7 \pm 0 \cdot 1$ respectively over plastic conditions, while secretion was lower on LN (Fig. 6A). Basal secretion of corticosterone by fasciculata cells was increased on CI and IV matrices by $2 \cdot 2 \pm 0 \cdot 1$ and $2 \cdot 7 \pm 0 \cdot 1$-fold over basal value, compared with plastic conditions, while FN had no effect. Corticosterone secretion was severely blunted on LN, with $75 \%$ lower production than on plastic (Fig. 6B). ACTH exhibited 

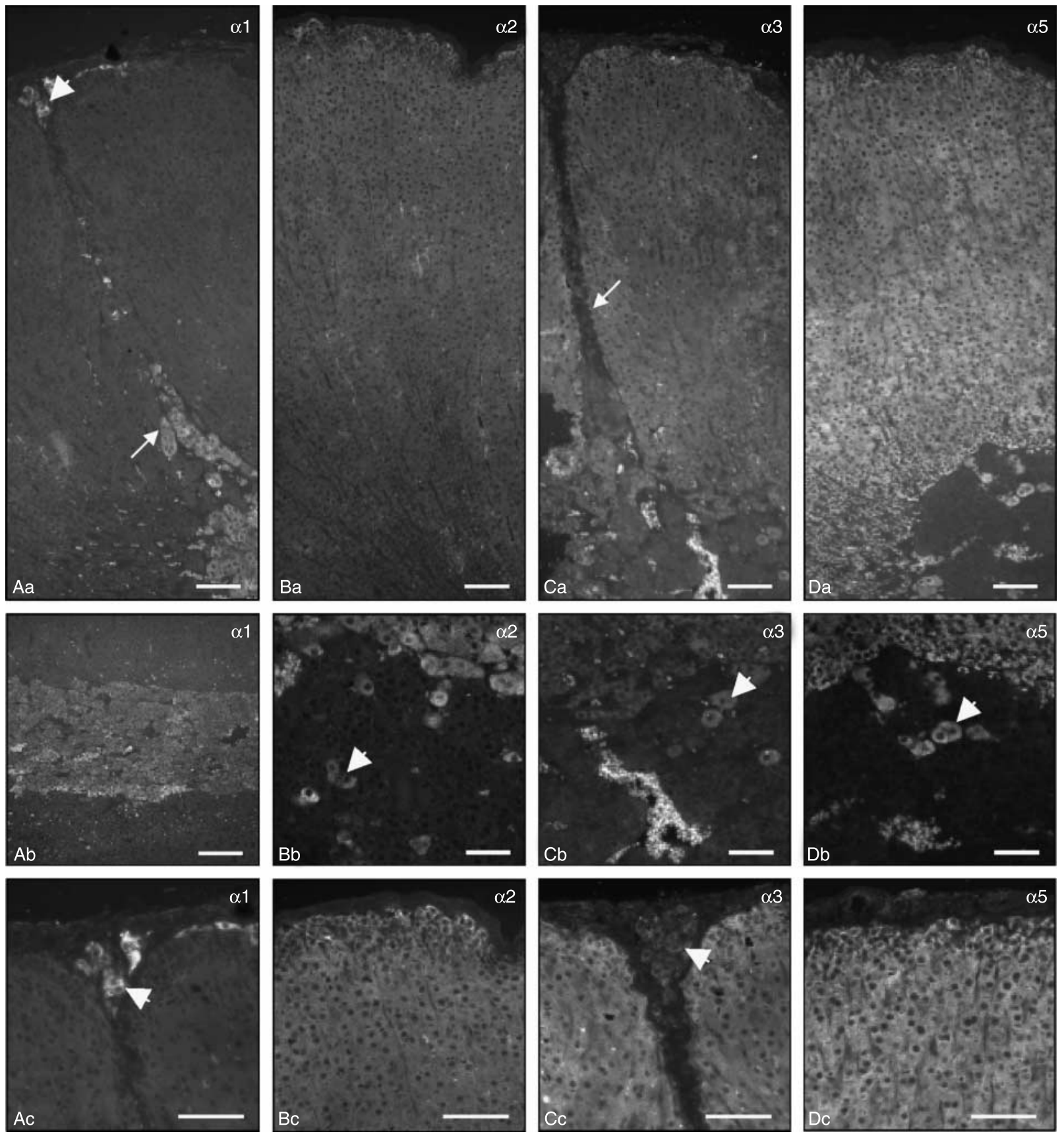

Figure 4 Immunodetection of integrin $\alpha 1, \alpha 2, \alpha 3$ and $\alpha 5$ subunits in adult rat adrenal gland. Paraffin-embedded sections (5 $\mu$ m) of adult rat adrenal gland were processed for immunofluorescence labelling as described in Materials and Methods. Aa and Ac: integrin $\alpha 1$ in the adrenal cortex; Ba and Bc: integrin $\alpha 2$ in the adrenal cortex; Ca and Cc: integrin $\alpha 3$ in the adrenal cortex; Da and Dc: integrin $\alpha 5$ in the adrenal cortex; Ab: integrin $\alpha 1$ in the adrenal medulla; Bb: integrin $\alpha 2$ in the adrenal medulla; Cb: integrin $\alpha 3$ in the adrenal medulla; Db: integrin $\alpha 5$ in the adrenal medulla. Images were acquired at magnification $10 \times($ Aab, Bab, Cab and Dab) and $30 \times(\mathrm{Ac}, \mathrm{Bc}, \mathrm{Cc}$ and Dc). Scale bars, $50 \mu \mathrm{m}$. Images are representative illustrations of more than five glands. Arrow: medullary rays; arrowhead: integrin $\alpha$ subunit labelling in the medullary tissue. 

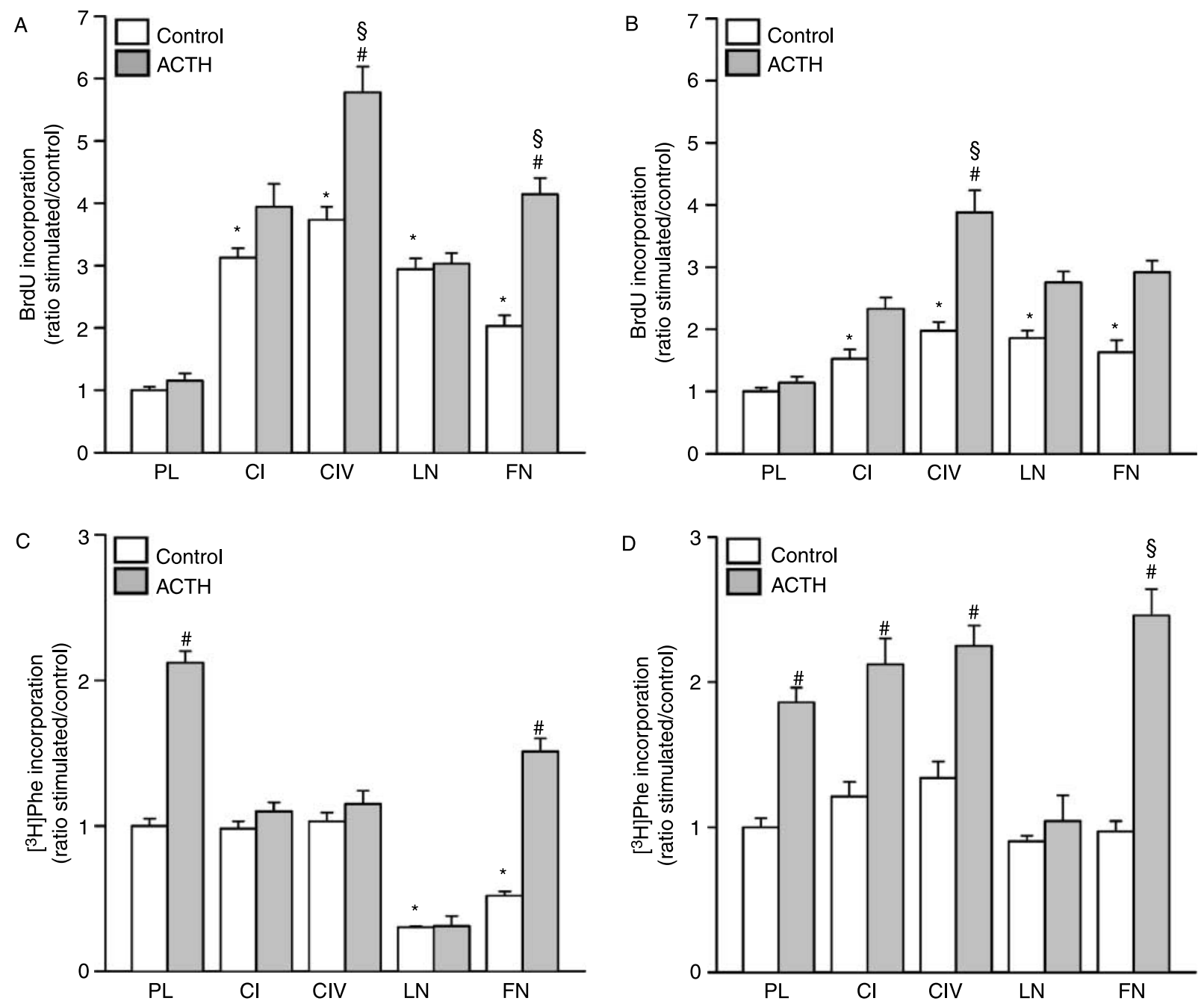

Figure 5 Effect of matrices and adrenocorticotropin (ACTH) on proliferation (A and B) and protein synthesis (C and D) in rat glomerulosa $(\mathrm{A}$ and $\mathrm{C}$ ) and fasciculata cells (B and D). Cells were plated onto plastic (PL), collagen I (CI), collagen IV (CIV), laminin (LN) and fibronectin (FN)-coated 96-well plates for proliferation studies $\left(30 \times 10^{3}\right.$ cells/well) and onto similarly coated 24 -well plates for protein content $\left(70 \times 10^{3}\right.$ cells/well). Glomerulosa $(A$ and $C)$ and fasciculata cells (B and D) were stimulated without or with $\mathrm{ACTH}(10 \mathrm{nM})$ daily for 3 days. Proliferation was measured by fluorescent $\mathrm{BrdU}$ incorporation whereas protein synthesis was assessed by $\left.{ }^{3} \mathrm{H}\right]$ phenylalanine incorporation. All methodologies are described in Materials and Methods. Results are expressed as means \pm s.E.M. of three experiments with each experimental condition containing six individual samples. Statistical significance: $* P<0 \cdot 01$, ECM comparison between control cells grown on plastic; ${ }^{\#} P<0 \cdot 01$, comparison between control and ACTH-treated cells; ${ }^{\S} P<0 \cdot 01$, ECM comparison between ACTH-treated cells on plastic.

strong acute stimulatory effects on all ECMs, in both glomerulosa and fasciculata cells with stimulating values ranging from $23 \cdot 0 \pm$ $1 \cdot 1$ to $37 \cdot 6 \pm 1 \cdot 1$-fold increases on FN and $\mathrm{LN}$ for glomerulosa cells and from $33 \cdot 5 \pm 2 \cdot 7$ to $66 \cdot 8 \pm 4 \cdot 4$-fold increases on CIV and LN for fasciculata cells (Fig. 6A and B).

In order to correlate secretion with steroidogenesis, expression of the key steroidogenic enzyme $3 \beta-\mathrm{HSD}$ was measured. As shown in Fig. 6C, 3-day culture on CI, CIV and FN increased $3 \beta-H S D$ expression, reaching $3 \cdot 1 \pm 0 \cdot 8$ and $4 \pm 0 \cdot 9$-fold increases on CIV for glomerulosa and fasciculata cells respectively, while LN decreased $3 \beta$-HSD expression by more than $35 \%$ for glomerulosa cells. These results indicate that matrices (FN, CI and IV) play a role in aldosterone and corticosterone production by enhancing expression of $3 \beta-$ HSD protein, whereas $\mathrm{LN}$ is not involved in steroid secretion.

cAMP production In glomerulosa cells, the highest stimulating effect of ACTH (at a concentration of $10 \mathrm{nM}$ ) was observed on CI, with a $38 \cdot 6 \pm 5 \cdot 8$-fold increase and an $\mathrm{ED}_{50}$ value of $0.78 \mathrm{nM}$, while on CIV, LN, FN or plastic, stimulation was respectively $23 \cdot 1 \pm 1 \cdot 3,25 \cdot 6 \pm 5 \cdot 6,17 \cdot 4 \pm$ 1.4 and $16 \cdot 5 \pm 5 \cdot 4$-fold increase over basal value, with respective $\mathrm{ED}_{50}$ values of $0.52,1.89$ and $0.28 \mathrm{nM}$ (Fig. 7A and $\mathrm{C}$ ). In fasciculata cells, the highest stimulation ratio was 

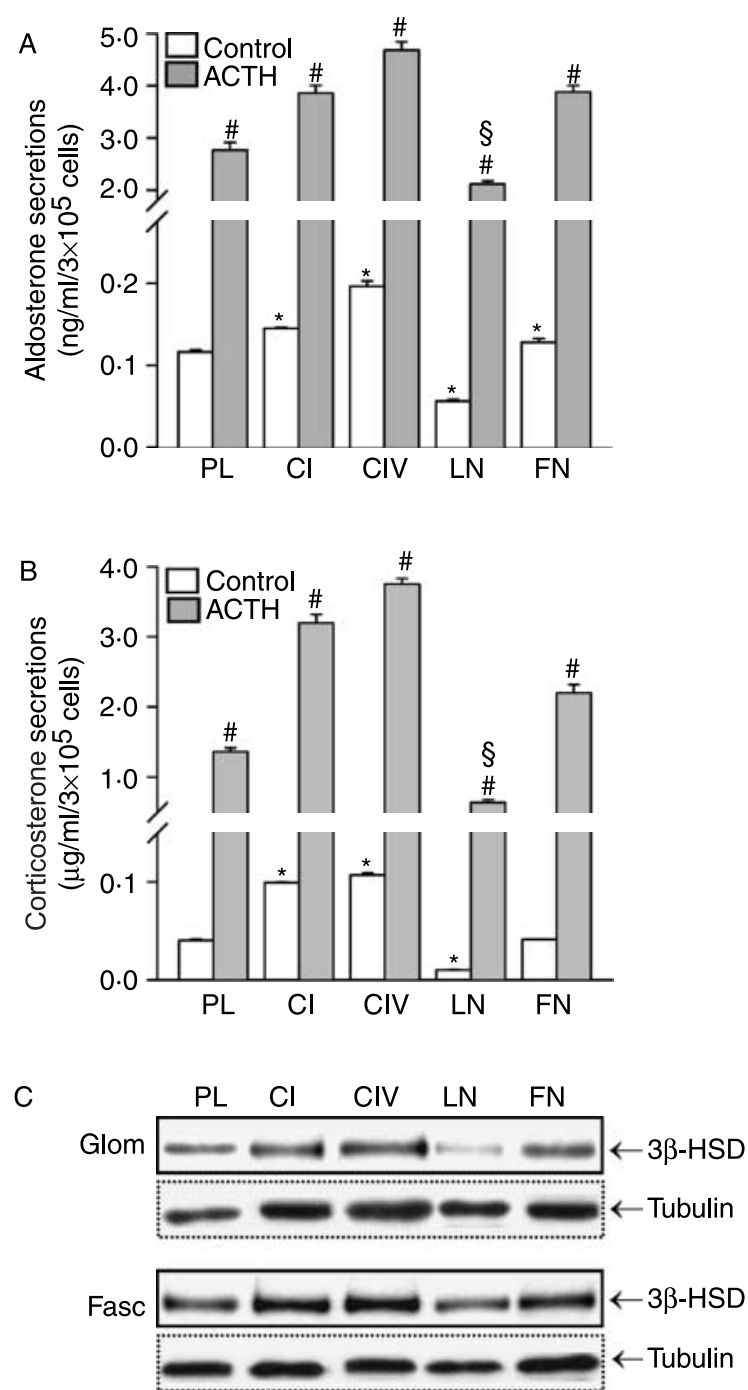

Figure 6 Effect of matrices and $\mathrm{ACTH}$ on steroid secretion in rat glomerulosa (A) and fasciculata cells (B). Cells were plated onto plastic $(\mathrm{PL})$, collagen I $(\mathrm{Cl})$, collagen IV $(\mathrm{CIV})$, laminin $(\mathrm{LN})$ or fibronectin (FN)-coated 24-well plates for secretion analysis $(15 \times$ $10^{4}$ cells/well). Steroid secretion of glomerulosa cells on matrices was measured by RIA. Glomerulosa (A) and fasciculata cells (B) were stimulated without or with ACTH $(10 \mathrm{nM})$ for $2 \mathrm{~h}$. All methodologies are described in Materials and Methods. Results are expressed as means \pm S.E.M. of three experiments with each experimental condition containing six individual samples. Statistical significance: ${ }^{*} P<0 \cdot 01$; ECM comparison between control cells grown on plastic; ${ }^{\#} P<0 \cdot 01$; comparison between control and ACTH-treated cells; ${ }^{\S} \mathrm{P}<0 \cdot 01$; ECM comparison between ACTHtreated cells on plastic. (C) Expression of 3 $\beta$-HSD. Glomerulosa (upper panel) and fasciculata cells (lower panel) were cultured for 3 days onto plastic (PL), collagen I (CI), collagen IV (CIV), laminin $(\mathrm{LN})$ or fibronectin (FN)-coated dishes. Cell lysates from equivalent numbers of cells $\left(1 \times 10^{6}\right.$ cells/Petri dish) were separated on $10 \%$ polyacrylamide gels and subjected to western blot analysis using specific antibodies against $3 \beta-\mathrm{HSD}$, as described in Materials and Methods. observed when cells were cultured on plastic, with a $25 \cdot 6 \pm$ 3.6-fold increase and an $\mathrm{ED}_{50}$ value of $0.79 \mathrm{nM}$, while on $\mathrm{CI}$, CIV, LN or FN, stimulation was respectively $11 \cdot 8 \pm 0 \cdot 8$, $9 \cdot 0 \pm 1 \cdot 8,10 \cdot 3 \pm 0 \cdot 1$ and $8 \cdot 8 \pm 0 \cdot 1$-fold increase over basal value, with respective $\mathrm{ED}_{50}$ values of $0.49,1.0$ and $1.7 \mathrm{nM}$ (Fig. 7B and D).

MAPK activation The basal phosphorylation of p38MAPK (Fig. 8A, C and D) and SAPK (stress-activated protein kinase; Fig. 8B, E and F) was not affected by ECMs in either cell type. In glomerulosa and fasciculata cells, ACTH activated p38MAPK by $1 \cdot 8 \pm 0 \cdot 3$ and $2 \cdot 8 \pm 0 \cdot 4$-fold (Fig. 9C and D) and SAPK/JNK by $1 \cdot 7 \pm 0 \cdot 4$ and $4 \cdot 5 \pm 0 \cdot 5$-fold respectively (Fig. $8 \mathrm{D}$ and $\mathrm{F}$ ). ECM did not modify basal activation of $\mathrm{p} 42 / \mathrm{p} 44^{\text {mapk }}$ while $\mathrm{ACTH}$ did not activate $\mathrm{p} 42 / \mathrm{p} 44^{\mathrm{mapk}}$ (data not shown).

Phase-contrast morphology of adrenocortical cells grown on CI, $I V, L N$ and FN matrices

In order to investigate possible correlation between function and morphology, cells were cultured on CI-, CIV-, LN- and FN-coated Petri dishes and examined under phase-contrast microscopy. After 3 days in culture, glomerulosa and fasciculata cells grown on plastic, CI and CIV formed a monolayer of cells with similar polygonal morphology and size (Fig. 9A-C and F$\mathrm{H})$. In contrast, glomerulosa and fasciculata cells grown on LN appeared as clusters of small superimposed rounded cells (Fig. 9D and I). A notable difference was also observed between glomerulosa and fasciculata cells cultured on FN. Glomerulosa cells exhibited monolayer of cells with polygonal morphology (Fig. 9E) while the majority of fasciculata cells appeared as clusters of small rounded cells (Fig. 9J).

\section{Colocalization of ECM components in whole rat adrenal gland}

Since LN lowered all basal values of protein synthesis and secretion compared with the other ECMs, colocalization patterns were examined. Indeed, components of the ECM interact with each other to form a structured network in supporting various cell functions (Kalluri 2003). In order to determine the putative association between these components, double immunofluorescence localization of these ECMs was performed. In Fig. 10Aa, colocalization of CI (green) and LN (red) was higher in zona glomerulosa and in the adrenal capsule compared with that found in zona fasciculata (Fig. 10Aa and $\mathrm{Ab}$ ). CIV (red) and LN (green) were colocalized both in the zona glomerulosa (Fig. 10Ba and $\mathrm{Bb}$ ) and zona fasciculata. Finally, FN (green) and LN (red) were also colocalized in zona glomerulosa and in zona fasciculata (Fig. 10Ca and $\mathrm{Cb}$ ), with a gradient decreasing from the zona glomerulosa towards the inner portion of the gland. In addition, FN exhibited exclusive staining in some 

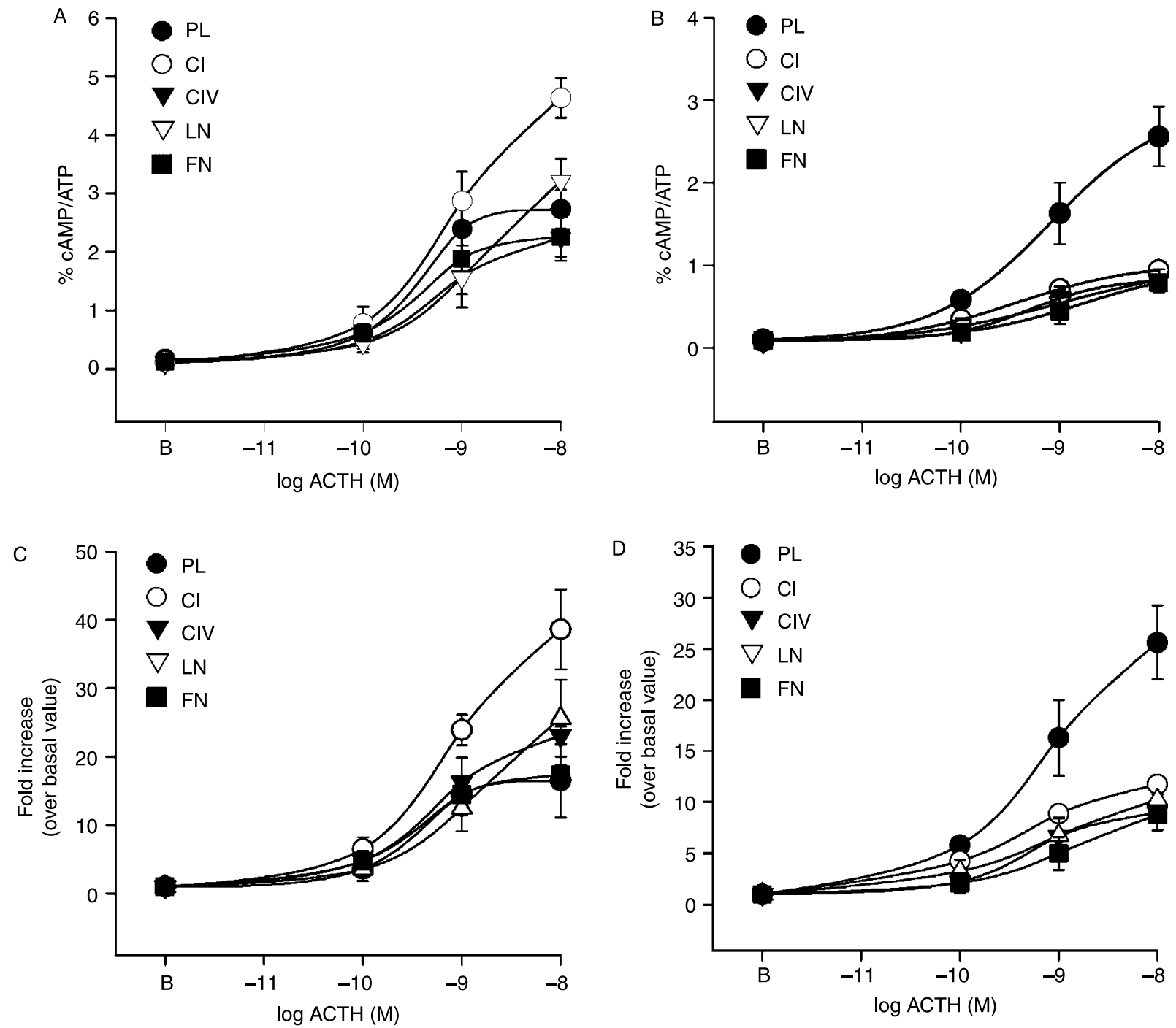

Figure 7 Effect of matrices on cAMP production induced by ACTH in glomerulosa cells (A and C), fasciculata cells (B and D) as well as in the entire gland. Cells were plated onto plastic $(\mathrm{PL})$, collagen I (CI), collagen IV (CIV), laminin (LN) or fibronectin (FN)-coated Petri dishes. Cells were labelled with $\left[{ }^{3} \mathrm{H}\right]$ adenine and were stimulated without or with ACTH $\left(10^{-10}, 10^{-9}\right.$ and $\left.10^{-8} \mathrm{M}\right)$. Cyclic AMP accumulation was measured as described in Materials and Methods. Results are expressed as the percentage of ATP transformed into CAMP (A and B) and are also expressed as the fold stimulation over basal values (C and D). Results are represented as means \pm s.E.M. of three experiments, each performed in triplicate.

regions of the zona glomerulosa as demonstrated by FN-specific green labelling (arrow, Fig. 10Ca).

\section{Discussion}

This study describes the localization of the main ECM components and integrins within the adult rat adrenal gland and establishes a relationship between ECM and cell functions in the adrenal cortex. In particular, FN, CI and CIV were found to favour steroid synthesis and secretion, while LN is clearly involved in proliferation and not in steroid secretion.
Furthermore, the results underline the unique distribution of integrin $\alpha 1$ in medulla, as exemplified in the medullary rays extending from the medulla to the capsule. Together, these results indicate that ECM signalling through integrins plays an active role, both in basal and in ACTH action and integration of cell responses.

Differential expression of ECM and integrins in adrenal gland cortex

The results herein are the first to document immunofluorescence localization of the main ECMs and integrins in the rat 
A

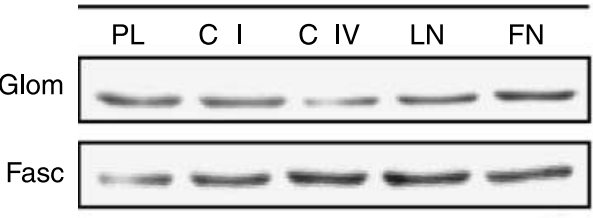

B

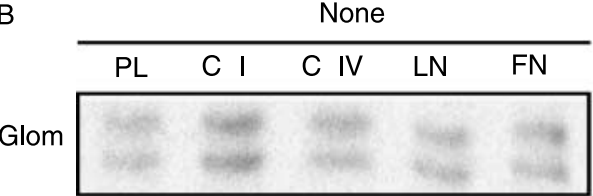

Fasc

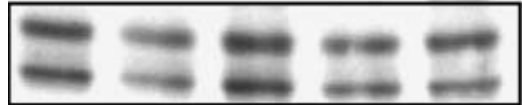

C

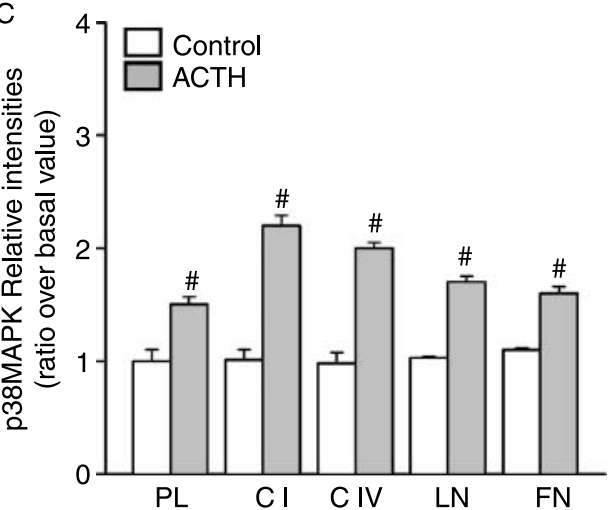

E

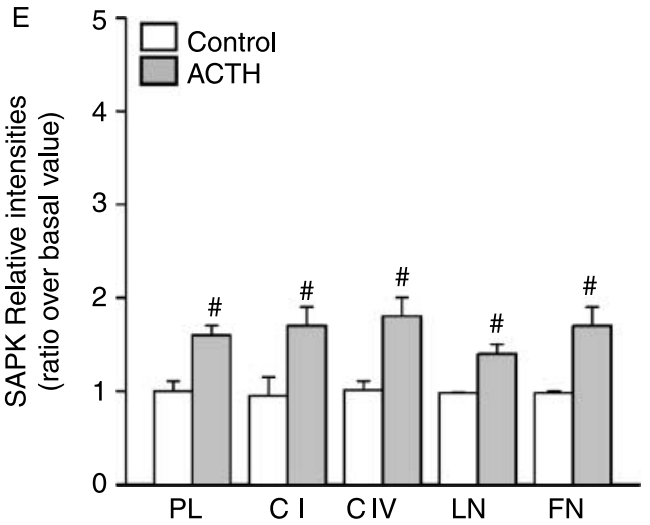

ACTH (30 min)
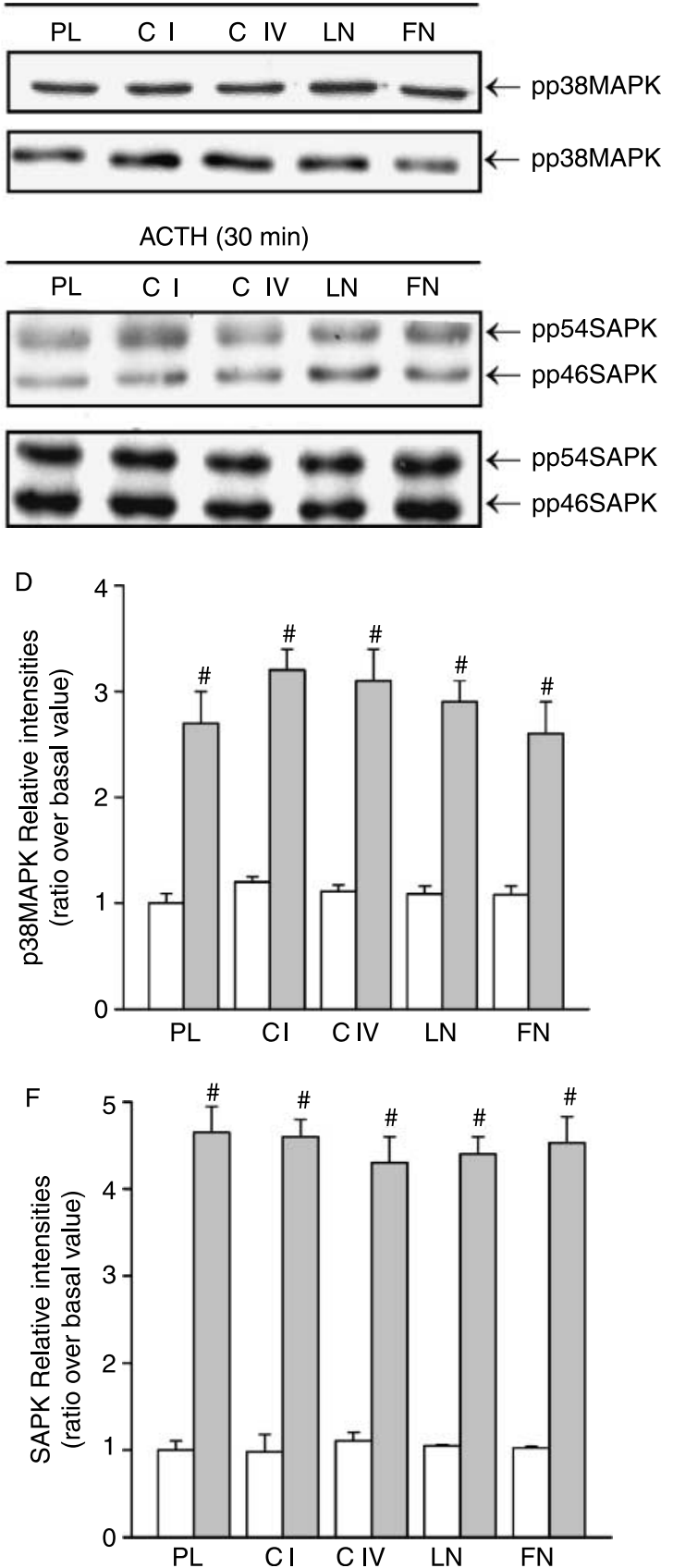

Figure 8 Effect of matrices and ACTH on activation of p38MAPK (A, C and D) and SAPK (B, E and F) in glomerulosa and fasciculata cells. Glomerulosa A and B upper panels and fasciculata cells $A$ and $B$ lower panels were cultured for 3 days onto plastic (PL), collagen I $(\mathrm{Cl})$, collagen IV $(\mathrm{CIV})$, laminin (LN) or fibronectin $(\mathrm{FN})$-coated dishes. Cell lysates from equivalent numbers of cells $\left(1 \times 10^{6}\right.$ cells/Petri dish) were separated on $10 \%$ polyacrylamide gels and subjected to western blot analyses with antibodies to phosphorylated p38 MAPK (1:1000) and phosphorylated SAPK (1:1000), as described in Materials and Methods. Effect of ECM and ACTH on p38MAPK (C and D) and SAPK (E and F) activation in glomerulosa ( $\mathrm{C}$ and $\mathrm{E})$ and fasciculata cells ( $\mathrm{D}$ and $\mathrm{F}$ ) as analysed by densitometry. All data represent the means \pm S.E.M. of four different experiments. Statistical significance: one-way ANOVA revealed a significant effect of ACTH-treated cells compared with basal values (control; ${ }^{\#} P<0 \cdot 01$ ). 

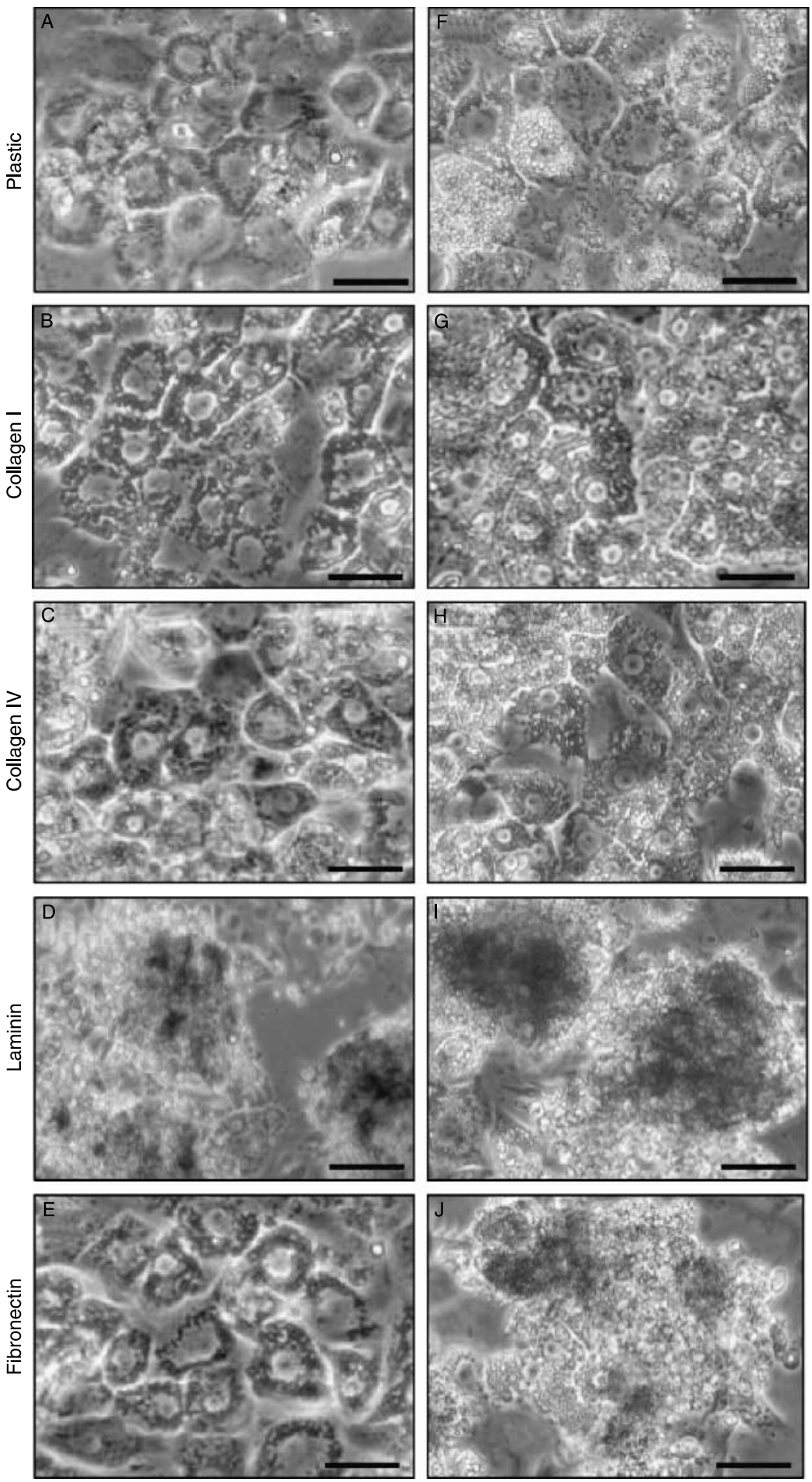

Figure 9 Phase-contrast morphology of rat glomerulosa (A-E) and fasciculata (F-J) cells grown on plastic ( $A$ and $F$ ), collagen I (B and $G)$, collagen IV (C and $H)$, laminin (D and I) and fibronectin (E and J). Cells were plated at an initial concentration of $5 \times 10^{4}$ cells on matrixcoated Petri dishes. Phase-contrast images were acquired after 3 days in culture with a Leica microscope equipped with a $32 \times$ objective. Images are representative illustrations of more than 50 cells originating from three different experiments. Scale bars, $20 \mu \mathrm{m}$. 

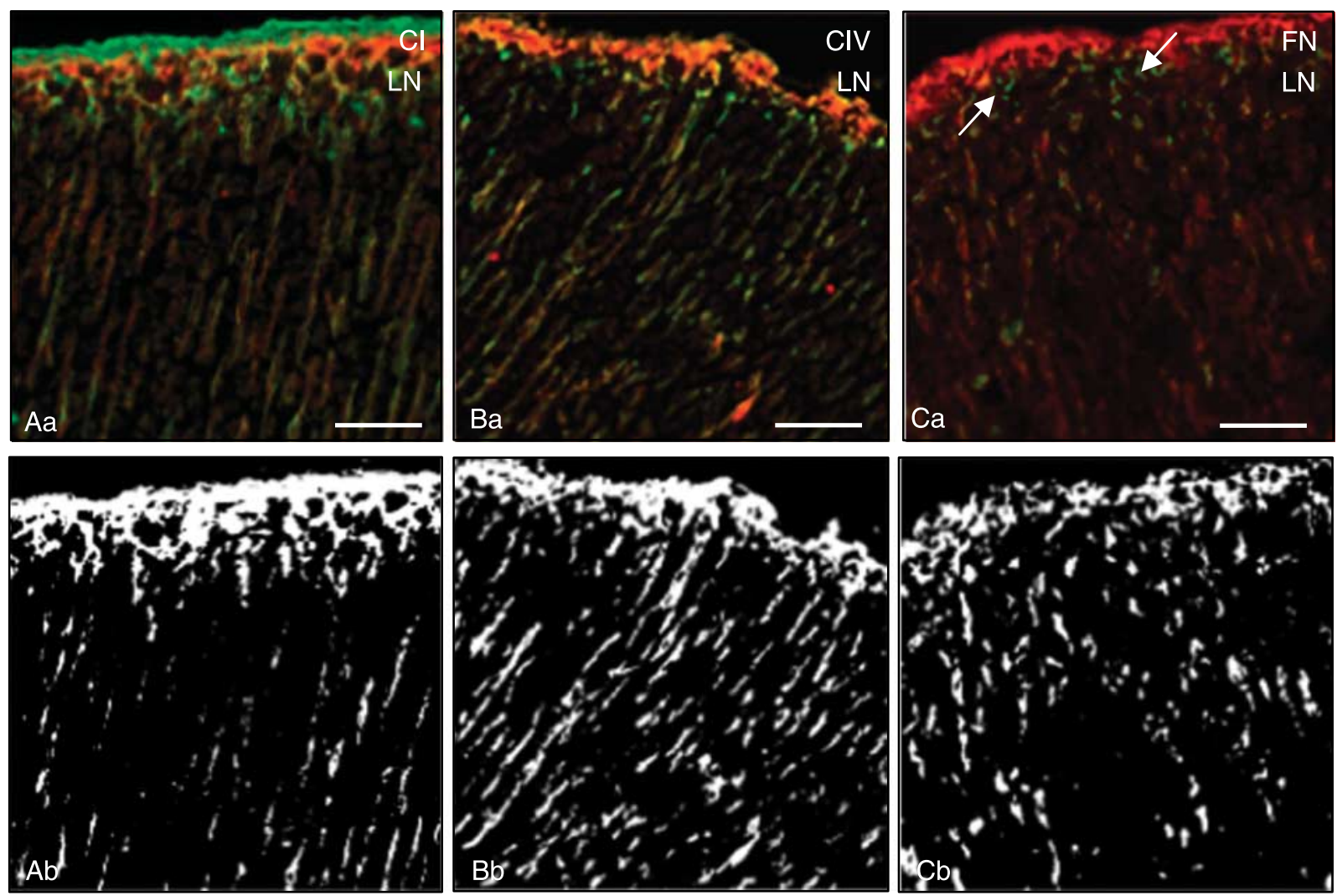

Figure 10 Colocalization of collagen I (CI), collagen IV (CIV), laminin (LN) and fibronectin (FN) in adult rat adrenal outer cortex zone. Frozen sections $(5-6 \mu \mathrm{m})$ of adult rat adrenal gland were processed for double immunofluorescence with Zenon technology as described in Materials and Methods. Binary images showing only the colocalized ECM components were generated using the Metamorph software Aa: double staining of $\mathrm{Cl}$ (green) and LN (red); Ba: double staining of CIV (green) and LN (red); Ca: double staining of FN (green) and LN (red); Panels Ab, $\mathrm{Bb}$ and $\mathrm{Cb}$ represent binary images showing only colocalized ECM components corresponding to yellow-coloured elements in $\mathrm{A}, \mathrm{B}$ and $\mathrm{C}$ respectively. Scale bars, $50 \mu \mathrm{m}$. Images are representative illustrations of more than five glands.

adrenal cortex. CIV staining was found to be abundant in both zona glomerulosa and zona fasciculata, with a gradient from the outer to the inner portion of the cortex. FN was found surrounding each glomerulosa cell and as discontinuous fibrils between the radial cords of cells and sinusoids. In the bovine adrenal gland, using immunochemistry, Pellerin et al. (1997) found FN expression surrounding entire glomeruli and as fibrillar structures underlining capillaries and sinusoids, with no labelling in glomerulosa cells. We found strong LN labelling in the capsule and around each individual glomerulosa cell, with weak labelling in the zona fasciculata. In bovine (Pellerin et al. 1997) and human adrenal cortex (Virtanen et al. 2003) on the other hand, LN was reported as uniformly distributed in the zonae glomerulosa, fasciculata and reticularis but was not detected in the capsule or medulla (Pellerin et al. 1997). In the medulla, our results revealed that CI was expressed around each individual chromaffin cell and around each cluster of cells, while CIV and LN were expressed only around clusters of chromaffin cells and FN restricted to the border of blood vessels. These results are in accordance with the observations of Kikuta et al. (1991) showing strong staining for collagens in the basement membrane underlying chromaffin cells, but differ from observations reported in the bovine adrenal gland where FN was not detected in chromaffin cells (Feige et al. 1998).

The most striking observation of the present study is the specific distribution of integrins between cortex and medulla, as exemplified in the rays containing medullary tissue extending across the cortex, called medullary rays (GalloPayet et al. 1987). For example, the $\alpha 1$ subunit exhibited strong expression in the medulla and medullary rays, but was virtually absent in the cortex, while, in contrast, the $\alpha 3$ subunit was strongly expressed in the cortex, and only in a few cells of the medulla. This unique distribution of integrins between cortex and medulla first indicates that $\alpha$ subunits of integrins represent excellent tools for outlining the presence of medullary rays crossing into the cortex, thus corroborating previous observations in rat (Gallo-Payet et al. 1987), porcine (Bornstein et al. 1991) and human (Bornstein et al. 1994) adrenal gland (for review see Ehrhart-Bornstein et al. 1998). Secondly, these observations support evidence as to how neuropeptides synthesized in the medulla, such as vasopressin 
(Grazzini et al. 1999), are exported to the zona glomerulosa through these medullary rays. In the human adrenal cortex, Virtanen et al. (2003) found a rather diffuse distribution of $\alpha 1$ subunits outside the cells in the stromal region, while $\alpha 2$ and $\alpha 3$ integrins were mainly expressed around glomerulosa cells.

\section{Influence of ECM and integrins on functional properties of adrenocortical cells}

Our results provide evidence that all ECM favour basal proliferation and modulate the effect of hormones. Indeed, ACTH-induced proliferation was observed only on CIV and FN matrices in glomerulosa cells and only on CIV in fasciculata cells, while protein synthesis was increased only on FN matrices in glomerulosa cells and on CI, CIV and FN in fasciculata cells. In addition, FN, CI and IV all increased basal aldosterone and corticosterone secretion while in glomerulosa cells, CI, CIV and FN enhanced acute ACTH action. These results support the previous studies of Ill \& Gospodarowicz (1982), Cheng \& Hornsby (1992) and Feige et al. (1998) whereby ECM components are among the factors necessary to promote steroid secretion and basal cell proliferation. A recent study using Matrigel (major components: LN and CIV) also clearly indicated that rat adrenocortical cells maintained both the ultrastructure as well as expression of steroidogenic enzymes until day 12 of culture (Spinazzi et al. 2006). Cell phase-contrast morphology performed in this study also correlated with functional activities. On plastic, CI, CIV and FN-coated dishes, glomerulosa cells exhibited a polygonal structure with clearly visible lipid droplets. In contrast, on LN and FN, fasciculata cells formed clusters of small cells, suggesting active proliferation. In addition, 3 $3-$ HSD expression as well as secretion was weak on these matrices, indicating that these two functions (proliferation and secretion) cannot occur simultaneously.

Of noted importance, we found that, in fasciculata cells, the large increase in cAMP accumulation previously described in cells cultured on plastic is not observed when cells are cultured on ECM. Indeed, while the stimulation ratio reached up to 25-fold increase over basal value on plastic (Gallo-Payet \& Payet 1989, Gallo-Payet et al. 1993), the fold increase only ranged from $9 \cdot 2 \pm 2 \cdot 1$ to $11 \cdot 2 \pm 1 \cdot 6$ on the ECM. In fact, these cAMP stimulation values on ECM are more in the range of the physiological response of the gland, since cAMP production in gland quarters stimulated with ACTH reached maximal stimulation ratios at about sixfold above basal values (data not shown). These results thus indicate that ECM/integrins possibly produce physical or modulatory constraints that limit interaction between ACTH receptor (the melanocortin 2 receptor)/Gs and adenylyl cyclases. This constraint disappears when cells are cultured on plastic. It has long been shown that collagen, LN and FN isoforms bind to each other in order to form the threedimensional network that forms the ECM (Kleinman et al. 1981, Woodley et al. 1983, Charonis et al. 1985). On the other hand, this constraint may be partly circumvented in zona glomerulosa, where ACTH-induced cAMP production is potentiated by the effect of ACTH on calcium influx and on calcium-sensitive adenyl cyclase isoform (for review see Gallo-Payet \& Payet 2003). Thus, it is possible that, in vivo, the role of one particular ECM component would be to incorporate other ECM proteins to the matrix and hence act indirectly on cell response in intact adrenal gland. LN colocalizes with CI and CIV and to a lesser extent with FN (Fig. 10). Since steroid secretions were lower on LN compared with plastic and other ECMs, it could be hypothesized that the in situ binding of $\mathrm{LN}$ to its integrin receptor may counterbalance the increase of CI- and CIVinduced aldosterone and corticosterone secretion in order to maintain a fine regulation of corticoid production. For instance, LN by binding to $\alpha 6 \beta 1, \alpha 7 \beta 1$ or $\alpha 6 \beta 4$ (Ekblom et al. 2003) may activate the pro-survival kinases of the protein kinase $\mathrm{B} / \mathrm{Akt}$ family which would inhibit signalling pathways induced by $\alpha 1 \beta 1, \alpha 2 \beta 1$ and $\alpha 3 \beta 1$ (collagen) and $\alpha 5 \beta 1$ (FN) integrins (Gu et al. 2002). To further add to this complexity, binding of integrins to different domains on LN has been shown to activate distinct signalling pathways (Desban \& Duband 1997, Desban et al. 2006). It is however not known how $\alpha 3$ or $\alpha 6$ signals differ from those transduced by $\alpha 5 \beta 1$ as reported by Gu et al. (2002). The $\alpha_{3} \beta_{1}$ integrin-mediated signalling events triggered by $\mathrm{LN}-10 / 11$ are quite dissimilar from those triggered by FN. LN-10/11 preferentially activates Rac, but not Rho, through an $\alpha_{3} \beta_{1}$ integrin-dependent pathway and enhances formation of lamellipodia. FN, however, preferentially activates Rho rather than Rac, leading to enhanced stress fibres and focal contact formation (Gu et al. 2002).

On the other hand, 3 days of cell culture on ECM does not affect basal MAPK activation (p42/p $44^{\text {mapk }}$, p38MAPK and SAPK/JNK). In glomerulosa and fasciculata cells, ACTH induced the activation of p38MAPK and JNK, but failed to activate $\mathrm{p} 42 / \mathrm{p} 44^{\mathrm{mapk}}$. These results are in agreement with previous studies demonstrating that $\mathrm{ACTH}$ does not stimulate p42/p44 ${ }^{\text {mapk }}$ activity (Chabre et al. 1995, Gallo-Payet et al. 1999), but increases SAPK/JNK activity (Watanabe et al. 1997). We have recently shown that the growth-promoting effect of Ang II involves both p42/p44 mapk and p38 MAPK activation, with a concomitant decrease in cell proliferation (Otis et al. 2005, Otis \& Gallo-Payet 2006, 2007).

In summary, the present results, obtained in cultured cells grown on various matrices, clearly indicate that ECM components and integrins may determine specific cell functions such as proliferation and steroid secretion. The precise localization of ECM components CI, CIV, LN and FN as well as their counter integrin receptors provide new insights into the role of these proteins in adult rat adrenal gland homeostasis. This is the first demonstration that ECM components such as CI, CIV and FN enhance the expression of $3 \beta-H S D$, thus conferring adrenocortical cells with the ability to respond intensively and with high efficiency to ACTH stimulation. In this regard, such priming could contribute or explain the rapid and important functional and morphological changes of the adrenal gland under ACTH challenges. 


\section{Acknowledgements}

The authors thank Lyne Bilodeau and Lucie Chouinard for their invaluable experimental assistance and Claude Roberge for stimulating discussions. This work was supported by grants from La Fondation des Maladies du Coeur du Québec and the Canadian Institute for Health Research to Nicole Gallo-Payet (MOP-10998) and Marcel D Payet (MT-6813). N G-P is a recipient of a Canada Research Chair in Endocrinology of the Adrenal Gland. The authors declare that there is no conflict of interest that would prejudice the impartiality of this scientific work.

\section{References}

Aplin AE, Howe A, Alahari SK \& Juliano RL 1998 Signal transduction and signal modulation by cell adhesion receptors: the role of integrins, cadherins, immunoglobulin-cell adhesion molecules, and selectins. Pharmacology Review 50 197-263.

Bornstein SR, Ehrhart-Bornstein M, Usadel H, Béckmann M \& Scherbaum WA 1991 Morphological evidence for a close interaction of chromaffin cells with cortical cells within the adrenal gland. Cell and Tissue Research 165 1-9.

Bornstein SR, Gonzalez-Hernandez JA, Ehrhart-Bornstein M, Adler G \& Scherbaum WA 1994 Intimate contact of chromaffin and cortical cells within the human adrenal gland forms the cellular basis for important intraadrenal interactions. Journal of Clinical Endocrinology and Metabolism $\mathbf{7 8}$ 225-232.

Campbell S, Otis M, Côté M, Gallo-Payet N \& Payet MD 2003 Connection between integrins and cell activation in rat adrenal glomerulosa cells: a role for Arg-Gly-Asp peptide in the activation of the $\mathrm{p} 42 / \mathrm{p} 44$ (mapk) pathway and intracellular calcium. Endocrinology 144 1486-1495.

Cater DB \& Stack-Dunne MP 1953 The histological changes in the adrenal of the hypophysectomised rat after treatment with pituitary preparations. Journal of Pathology and Bacteriology 66 119-133.

Chabre O, Cornillon F, Bottari SP, Chambaz EM \& Vilgrain I 1995 Hormonal regulation of mitogen-activated protein kinase activity in bovine adrenocortical cells: cross-talk between phosphoinositides, adenosine $3^{\prime}, 5^{\prime}$ monophosphate, and tyrosine kinase receptor pathways. Endocrinology 136 956-964.

Chamoux E, Narcy A, Lehoux JG \& Gallo-Payet N 2002 Fibronectin, laminin, and collagen IV as modulators of cell behavior during adrenal gland development in the human fetus. Journal of Clinical Endocrinology and Metabolism 87 1819-1828.

Charonis AS, Tsilibary EC, Yurchenco PD \& Furthmayr H 1985 Binding of laminin to type IV collagen: a morphological study. Journal of Cell Biology $1001848-1853$.

Cheng CY \& Hornsby PJ 1992 Expression of 11 beta-hydroxylase and 21-hydroxylase in long-term cultures of bovine adrenocortical cells requires extracellular matrix factors. Endocrinology 130 2883-2889.

Desban N \& Duband JL 1997 Avian neural crest cell migration on laminin: interaction of the alpha1beta 1 integrin with distinct laminin-1 domains mediates different adhesive responses. Journal of Cell Science 110 2729-2744.

Desban N, Lissitzky JC, Rousselle P \& Duband JL 2006 Alpha1beta1-integrin engagement to distinct laminin-1 domains orchestrates spreading, migration and survival of neural crest cells through independent signaling pathways. Journal of Cell Science 119 3206-3218.

Ehrhart-Bornstein M, Hinson JP, Bornstein SR, Scherbaum WA \& Vinson GP 1998 Intraadrenal interactions in the regulation of adrenocortical steroidogenesis. Endocrine Reviews 19 101-143.

Ekblom P, Lonai P \& Talts JF 2003 Expression and biological role of laminin-1. Matrix Biology 22 35-47.

Feige JJ, Keramidas M \& Chambaz EM 1998 Hormonally regulated components of the adrenocortical cell environment and the control of adrenal cortex homeostasis. Hormone and Metabolic Research 30 421-425. van der Flier A \& Sonnenberg A 2001 Function and interactions of integrins. Cell and Tissue Research 305 285-298.

Forti FL, Dias MH \& Armelin HA 2006 ACTH receptor: ectopic expression, activity and signaling. Molecular and Cellular Biochemistry 293 147-160.

Gallo-Payet N \& Payet MD 1989 Excitation-secretion coupling: involvement of potassium channels in ACTH-stimulated rat adrenocortical cells. Journal of Endocrinology 120 409-421.

Gallo-Payet N \& Payet MD 2003 Mechanism of action of ACTH: beyond cAMP. Microscopy Research and Technique 61 275-287.

Gallo-Payet N, Pothier P \& Isler H 1987 On the presence of chromaffin cells in the adrenal cortex: their possible role in adrenocortical function. Biochemistry and Cell Biology 65 588-592.

Gallo-Payet N, Payet MD, Chouinard L, Balestre MN \& Guillon G 1993 A model for studying regulation of aldosterone secretion: freshly isolated or cultured cells. Cellular Signalling 5 651-666.

Gallo-Payet N, Cote M, Chorvatova A, Guillon G \& Payet MD 1999 Cyclic AMP-independent effects of ACTH on glomerulosa cells of the rat adrenal cortex. Journal of Steroid Biochemistry and Molecular Biology 69 335-342.

Giancotti FG 2000 Complexity and specificity of integrin signalling. Nature Cell Biology 2 E13-E14.

Giancotti FG \& Tarone G 2003 Positional control of cell fate through joint integrin/receptor protein kinase signaling. Annual Review of Cell and Developmental Biology 19 173-206.

Gonzalez RR, Palomino A, Boric A, Vega M \& Devoto L 1999 A quantitative evaluation of alpha1, alpha4, alphaV and beta3 endometrial integrins of fertile and unexplained infertile women during the menstrual cycle. A flow cytometric appraisal. Human Reproduction 14 2485-2492.

Grazzini E, Breton C, Derick S, Andres M, Raufaste D, Rickwaert F, Boccara G, Colson P, Guerineau NC, Serradeil-le Gal C et al. 1999 Vasopressin receptors in human adrenal medulla and pheochromocytoma. Journal of Clinical Endocrinology and Metabolism 84 2195-2203.

Gu J, Fujibayashi A, Yamada KM \& Sekiguchi K 2002 Laminin-10/11 and fibronectin differentially prevent apoptosis induced by serum removal via phosphatidylinositol 3-kinase/Akt- and MEK1/ERK-dependent pathways. Journal of Biological Chemistry 277 19922-19928.

Houslay MD \& Kolch W 2000 Cell-type specific integration of cross-talk between extracellular signal-regulated kinase and cAMP signaling. Molecular Pharmacology 58 659-668.

Hynes RO 1992 Integrins: versatility, modulation, and signaling in cell adhesion. Cell 69 11-25.

Ill CR \& Gospodarowicz D 1982 Factors involved in supporting the growth and steroidogenic functions of bovine adrenal cortical cells maintained on extracellular matrix and exposed to a serum-free medium. Journal of Cellular Physiology 113 373-384.

Kalluri R 2003 Basement membranes: structure, assembly and role in tumour angiogenesis. Nature Reviews. Cancer 3 422-433.

Kikuta A, Ohtani O \& Murakami T 1991 Three-dimensional organization of the collagen fibrillar framework in the rat adrenal gland. Archives of Histology and Cytology 54 133-144.

Kleinman HK, Wilkes CM \& Martin GR 1981 Interaction of fibronectin with collagen fibrils. Biochemistry 20 2325-2330.

Le Bellego F, Pisselet C, Huet C, Monget P \& Monniaux D 2002 Lamininalpha6beta1 integrin interaction enhances survival and proliferation and modulates steroidogenesis of ovine granulosa cells. Journal of Endocrinology 172 45-59.

Lotfi CF \& Armelin HA 2001 cfos and cjun antisense oligonucleotides block mitogenesis triggered by fibroblast growth factor-2 and ACTH in mouse Y1 adrenocortical cells. Journal of Endocrinology 168 381-389.

Mazzocchi G, Malendowicz LK, Rebuffat P, Robba C, Gottardo G \& Nussdorfer GG 1986 Short- and long-term effects of ACTH on the adrenal zona glomerulosa of the rat. A coupled stereological and enzymological study. Cell and Tissue Research 243 303-310.

Mizejewski GJ 1999 Role of integrins in cancer: survey of expression patterns. Proceedings of the Society for Experimental Biology and Medicine 222 124-138.

Otis M \& Gallo-Payet N 2006 Differential involvement of cytoskeleton and rho-guanosine $5^{\prime}$-triphosphatases in growth-promoting effects of angiotensin II in rat adrenal glomerulosa cells. Endocrinology 147 5460-5469. 
Otis M \& Gallo-Payet N 2007 Role of MAPKs in angiotensin II-induced steroidogenesis in rat glomerulosa cells. Molecular and Cellular Endocrinology 265 126-130.

Otis M, Campbell S, Payet MD \& Gallo-Payet N 2005 Angiotensin II stimulates protein synthesis and inhibits proliferation in primary cultures of rat adrenal glomerulosa cells. Endocrinology 146 633-642.

Pellerin S, Keramidas M, Chambaz EM \& Feige JJ 1997 Expression of laminin and its possible role in adrenal cortex homeostasis.

Endocrinology 138 1321-1327.

Penhoat A, Naville D \& Begeot M 2001 The adrenocorticotrophic hormone receptor. Current Opinion in Endocrinology and Diabetes 8 112-117.

Rainey WE 1999 Adrenal zonation: clues from 11beta-hydroxylase and aldosterone synthase. Molecular and Cellular Endocrinology 151 151-160.

Schwartz MA 2001 Integrin signaling revisited. Trends in Cell Biology 11 466-470.

Sewer MB \& Waterman MR 2003 ACTH modulation of transcription factors responsible for steroid hydroxylase gene expression in the adrenal cortex. Microscopy and Research Technique 61 300-307.

Spinazzi R, Petrelli L, Guidolin D, Carraro G, Casale V, Tortorella C, Neri G, Albertin G, Andreis PG \& Nussdorfer GG 2006 In vitro culture on Matrigel favors the long-term maintenance of rat zona glomerulosa-cell differentiated phenotype. International Journal of Molecular Medecine 17 1101-1110.

Tamkun JW, DeSimone DW, Fonda D, Patel RS, Buck C, Horwitz AF \& Hynes RO 1986 Structure of integrin, a glycoprotein involved in the transmembrane linkage between fibronectin and actin. Cell 46 271-282.
Thomas M, Keramidas M, Monchaux E \& Feige JJ 2003 Role of adrenocorticotropic hormone in the development and maintenance of the adrenal cortical vasculature. Microscopy Research and Technique 61 247-251.

Thomas M, Keramidas M, Monchaux E \& Feige JJ 2004 Dual hormonal regulation of endocrine tissue mass and vasculature by adrenocorticotropin in the adrenal cortex. Endocrinology 145 4320-4329.

Virtanen I, Korhonen M, Petajaniemi N, Karhunen T, Thornell LE, Sorokin LM \& Konttinen YT 2003 Laminin isoforms in fetal and adult human adrenal cortex. Journal of Clinical Endocrinology and Metabolism 88 4960-4966.

Wang J \& Milner R 2006 Fibronectin promotes brain capillary endothelial cell survival and proliferation through alpha5beta 1 and alphavbeta 3 integrins via MAP kinase signalling. Journal of Neurochemistry 96 148-159.

Watanabe G, Pena P, Albanese C, Wilsbacher LD, Young JB \& Pestell RG 1997 Adrenocorticotropin induction of stress-activated protein kinase in the adrenal cortex in vivo. Journal of Biological Chemistry 272 20063-20069.

Woodley DT, Rao CN, Hassell JR, Liotta LA, Martin GR \& Kleinman HK 1983 Interactions of basement membrane components. Biochimica et Biophysica Acta 761 278-283.

Received in final form 12 March 2007

Accepted 14 March 2007

Made available online as an Accepted Preprint 16 March 2007 